\title{
HYDROLOGY OF LAKES CLARA AND VANDERCOOK IN NORTH-CENTRAL WISCONSIN
}

By D. A. Wentz and W. J. Rose

\section{U.S. GEOLOGICAL SURVEY}

Water-Resources Investigations Report 89-4204

Prepared in cooperation with

WISCONSIN DEPARTMENT OF NATURAL RESOURCES 


\title{
U.S. DEPARTMENT OF THE INTERIOR MANUEL LUJAN, JR., Secretary
}

\author{
U.S. GEOLOGICAL SURVEY \\ Dallas L. Peck, Director
}

For additional information write to:

\section{District Chief}

U.S. Geological Survey

6417 Normandy Lane

Madison, WI 53719
Copies of this report can be purchased from:

U.S. Geological Survey

Books and Open-File Reports Section

Federal Center, Box 25425

Building 810

Denver, CO 80225 


\section{CONTENTS}

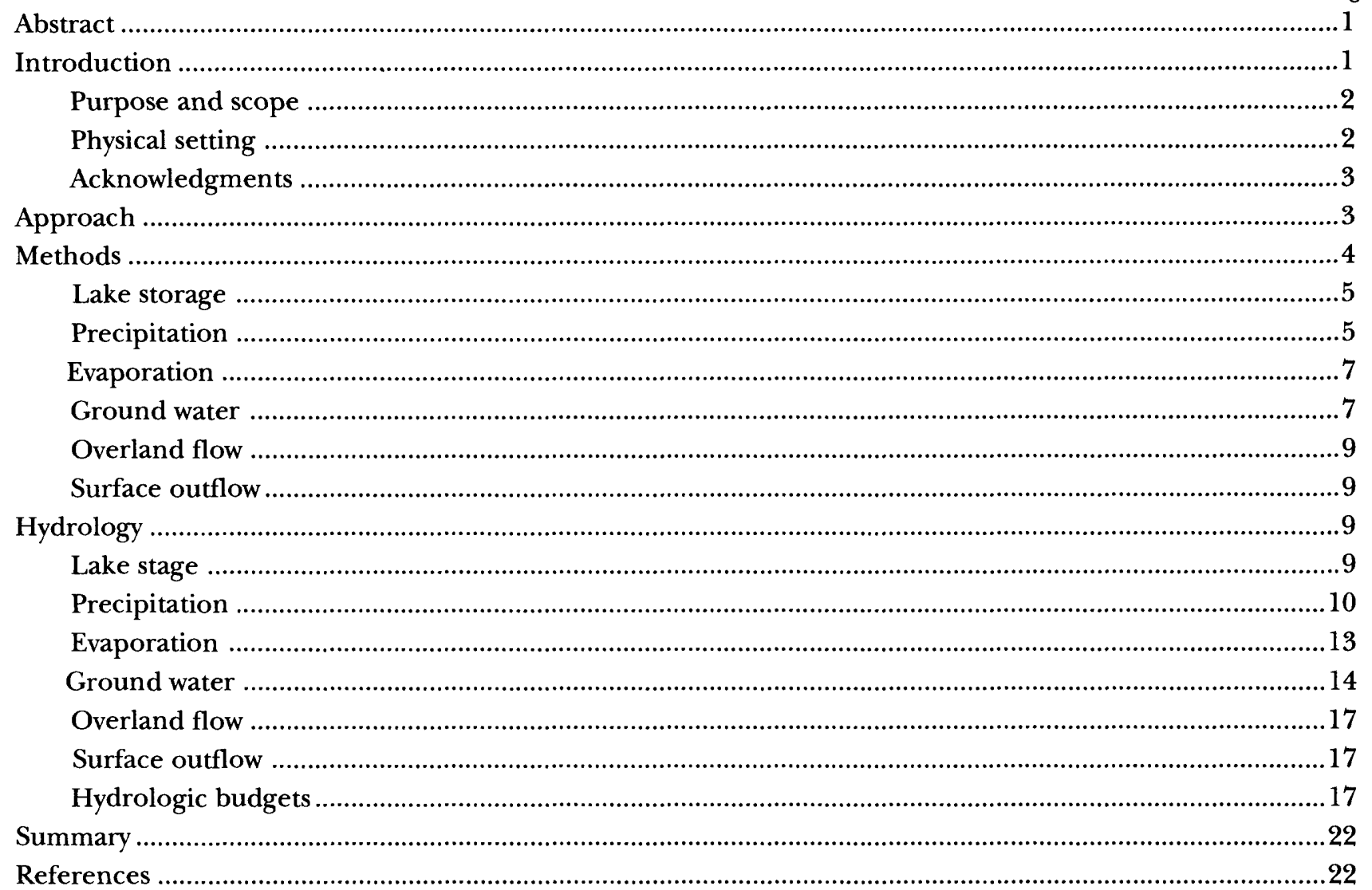

\section{ILLUSTRATIONS}

Figure 1. Map showing locations of Lakes Clara and Vandercook in north-central Wisconsin .......................2

2. Diagram showing interrelations among hydrologic-budget components

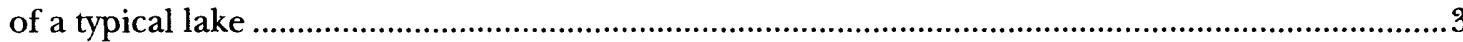

3. Map showing locations of hydrologic instrumentation at the Lake Clara study area ...................... 4

4. Map showing locations of hydrologic instrumentation at the Vandercook Lake

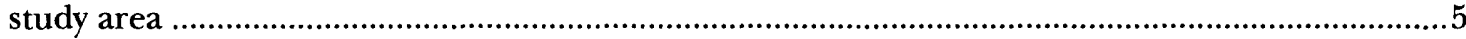

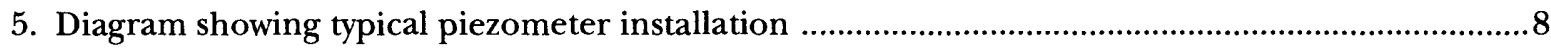

6. Graph showing precipitation, snowpack, lake stage, and water table at Lake Clara .......................10

7. Graph showing precipitation, snowpack, lake stage, and water table

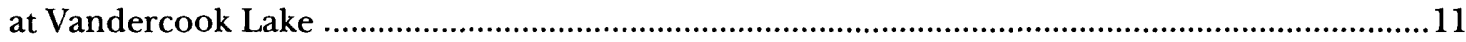

8. Graphs showing stage-area and stage-volume curves for Lake Clara (August 4, 1980) and Vandercook Lake (March 23, 1982)

9. Graph showing monthly lake/pan coefficients for evaporation at Rainbow Reservoir, 1971-83.

10. Graphs showing monthly evaporation at Lakes Clara and Vandercook .......................................15

11. Map showing water-table configuration at Lake Clara, June 3-4, 1982 ........................................16

12. Graph showing lake stage and adjacent water table at Lake Clara ..................................................17

13. Map showing water table configuration at Vandercook Lake, June 1-2, 1982 .............................. 18

14. Graph showing lake stage and adjacent water table at Vandercook Lake .....................................19 
15. Graphs showing monthly net ground-water flow to and from Lakes Clara and Vandercook

16. Graphs showing monthly overland flow to and surface outflow from Lake Clara

TABLES

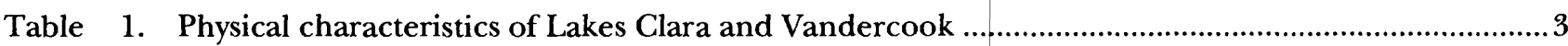

2. Description of instrumentation for hydrologic-budget data collection.....................................6

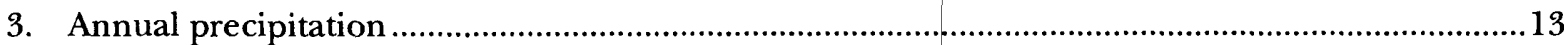

4. Regression relations between daily rainfall catch in observer-read and

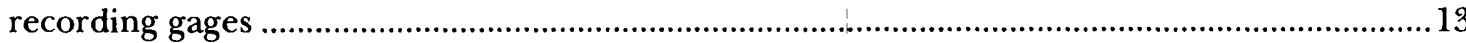

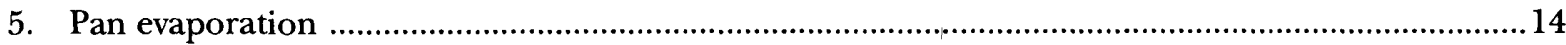

6. Horizontal hydraulic conductivity calculated from slug tests ...................................................... 17

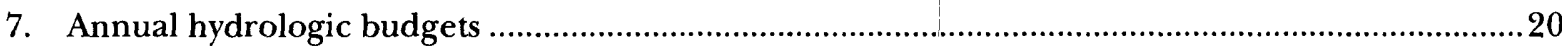

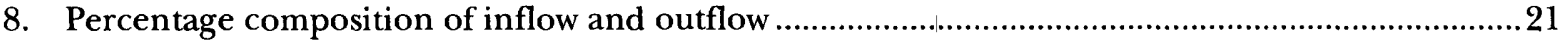

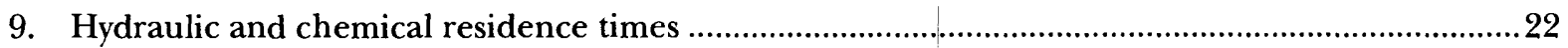

\section{CONVERSION FACTORS AND ABBREVIATIONS}

For the use of readers who prefer inch-pound units, rather than the metric (International System) units in this report, values may be converted using the following factors:

\begin{tabular}{l|c|c}
$\begin{array}{l}\text { Multiply SI unit } \\
\text { millimeter }(\mathrm{mm})\end{array}$ & By & To obtain inch-pound unit \\
meter $(\mathrm{m})$ & 0.03937 & inch (in.) \\
kilometer $(\mathrm{km})$ & 3.281 & foot $(\mathrm{ft})$ \\
hectare $(\mathrm{ha})$ & .6214 & mile $(\mathrm{mi})$ \\
square meter $\left(\mathrm{m}^{2}\right)$ & 2.471 & acre \\
cubic meter $\left(\mathrm{m}^{3}\right)$ & 10.76 & square $\mathrm{ft}\left(\mathrm{ft}^{2}\right)$ \\
meter per day $(\mathrm{m} / \mathrm{d})$ & 35.31 & cubic foot $\left(\mathrm{ft}^{3}\right)$
\end{tabular}

Sea level: In this report, "sea level" refers to the National Geodetic Vertical Datum of 1929 (NGVD of 1929)a geodetic datum derived from a general adjustment of the first-order level nets of both the United States and Canada, formerly called "Sea Level Datum of 1929." 


\title{
HYDROLOGY OF LAKES CLARA AND VANDERCOOK IN NORTH-CENTRAL WISCONSIN
}

\author{
By D. A. Wentz and W. J. Rose
}

\begin{abstract}
Lakes Clara and Vandercook are 33- and 43-hectare lakes, respectively, located in predominantly sandy outwash in north-central Wisconsin. Annual precipitation at National Weather Service stations during the 1951-80 calendar years averaged 794 millimeters near Lake Clara and 834 millimeters near Vandercook Lake. During the 1981 water year, annual precipitation measured at the lakes as part of this study was 3 percent below average for Lake Clara and 16 percent below average for Vandercook Lake. Annual precipitation was 6 to 21 percent above average for the two lakes during the 1982 and 1983 water years. Lake stage and water-table altitudes were relatively constant at Lake Clara throughout the 3 water years of study and at Vandercook Lake during the 1981 and 1982 water years; however, Vandercook Lake stage increased 0.2 meter, and the upgradient water table increased 0.3 meter, during the 1983 water year.

Hydrologic budgets show that lake inflow was dominated by precipitation ( 77 to 91 percent for Lake Clara and 79 to 87 percent for Vandercook Lake). Ground water accounted for the remaining inflow to Vandercook Lake; however, Lake Clara received approximately equal contributions from ground-water inflow and overland flow. Evaporation was the major form of lake outflow (59 to 75 percent for Lake Clara and 59 to 63 percent for Vandercook Lake). The remaining outflow from Vandercook Lake was to the ground-water system, but Lake Clara lost approximately equal amounts by surface and ground-water outflow. Hydraulic residence times were 4 to 5 years for both lakes. Chemical residence times for conservative constituents were 11 to 21 years for Lake Clara and 10 to 13 years for Vandercook Lake.
\end{abstract}

\section{INTRODUCTION}

Shortly after it was recognized that acid deposition may be spreading from the northeastern United States to the Midwest (Cogbill and Likens, 1974; Cogbill, 1976), the Wisconsin Department of Natural Resources (1980) expressed concern about the potential for adverse effects on lakes in northern Wisconsin. One area of particular importance is the Northern Highland Lake District (fig. 1), which encompasses one of the largest concentrations of lakes in the world (Martin, 1965). The features of this region were created 10,000 to 12,000 years ago when the last glaciers receded from Wisconsin (Hadley, 1976; Attig, 1985); the region is estimated to include more than 2,500 lakes. The lakes may be particularly sensitive to acid deposition because the glacial deposits commonly are sandy and contain little or no carbonate (Attig, 1985).

Prediction of the responses of lakes to acid deposition requires an understanding of the interactions of the lakes with their surroundings. The most basic of these interactions is described by the hydrologic or water budget, that is, how the volume of water in lake storage is affected by variations in water inflow and outflow rates.

In Wisconsin, most previous attempts to construct hydrologic budgets for lakes have been associated with eutrophication investigations. These include studies of Little St. Germain and Muskellunge Lakes (Hackbarth, 1968), Mirror and Shadow Lakes (Possin, 1973), White Clay Lake (Tolman, 1975), Lake Wingra (Oakes and others, 1975; Novitzki and Holmstrom, 1979), Pickerel Lake (Hennings, 1978), and Delavan Lake (Field and Duerk, 1988). Other studies, such as those of Cedar Lake (McLeod, 1980) and of three ponds in Middleton (House, 
1984), have used hydrologic budgets to assist in the analysis and prediction of lake-level fluctuations.

In each of the above studies, at least one of the inflows or outflows was (1) approximated from available data that were not collected as part of the study, or (2) calculated as the residual from the remaining terms in the hydrologic-budget equation. Errors associated with approximated terms are difficult to assess. If a term is calculated as a residual, errors associated with the measured terms are included in the residual (Winter, 1978, 1981). Further, if any term of the hydrologic budget is assumed to be insignificant, any deviation from this assumption also is included in the residual (Winter, 1978).

A particular disadvantage of calculating groundwater flow as the residual from the hydrologic-budget equation is that only net ground-water flow is determined. Because the same net value can result from an infinite set of ground-water inflows and outflows, this value provides no information about the magnitudes of the inflows or outflows. A small residual may give the false impression of little ground-water interaction, particularly in flow-through situations (Winter, 1981).

In October 1980, the U.S. Geological Survey, in cooperation with the Wisconsin Department of Natural Resources, began hydrologic-budget investigations at Lakes Clara and Vandercook (fig. 1) in the Northern Highland Lake District. The studies were conducted to provide knowledge of how seepage lakes interact with their hydrologic environments. Information gained from the studies will be useful in understanding and predicting chemical responses of lakes to potential increases in deposition acidity.

\section{Purpose and Scope}

This report describes the results of the first 3 water years-October 1980 through September 1983-of the hydrologic-budget studies at Lakes Clara and Vandercook. The studies have provided detailed measurements and analyses of each term in the hydrologic-budget equation-lake stage, precipitation, evaporation, groundwater flow, overland flow, and surface outflow.

\section{Physical Setting}

Topography near Lakes Clara and Vandercook is gently rolling, with altitudes of approximately $460 \mathrm{~m}$ (meters) above sea level at Lake Clara and $495 \mathrm{~m}$ at Vandercook Lake. Local relief is 15 to $30 \mathrm{~m}$ at Lake Clara and 10 to $15 \mathrm{~m}$ at Vandercook Lake.

Glacial deposits near Lake Clara range from lowpermeability till to sandy outwash; the soils that have developed on these deposits are primarily loamy sands (Hole, 1976). At Vandercook Lake, sandy loam soils have formed on the predominantly sand-and-gravel-outwash deposits. Peat deposits occur in depressions at both study areas.

Vegetation surrounding Lake Clara is primarily mixed hardwood with red-pine plantation and some agriculture. Seven permanent residences and two summer cottages are located around the lake. Near Vandercook Lake, vegetation is comprised mainly of second-growth white pine, interspersed with aspen, birch, and mixed hardwoods. Several areas have been clearcut by commercial loggers; however, these plots generally are less than 1 hectare in size and are not adjacent to the lake. The northern half of the lakeshore is completely forested, whereas the southern half contains 36 dwellings, most of which are occupied seasonally.

Climate near Lakes Clara and Vandercook can be described as continental. January, with an average temperature of $-12.6^{\circ} \mathrm{C}$ (degrees Celsius), was the coldest month during the period $1951-80$ at two National Weather Service (NWS) stations within $23 \mathrm{~km}$ (kilometers) of Vandercook Lake; July (average temperature, $19.1^{\circ} \mathrm{C}$ ) was the warmest month. At Lake Clara, $50 \mathrm{~km}$ to the south, temperatures were about $1{ }^{\circ} \mathrm{C}$ greater. As discussed later, mean annual precipitation for 1951-80 was $834 \mathrm{~mm}$ (millimeters) at Vandercook Lake and 794 $\mathrm{mm}$ at Lake Clara. Snowfall at Vandercook Lake averaged approximately $1.8 \mathrm{~m}$ annually for the period 194977 (Wisconsin Agriculture Reporting Service, 1978), whereas the average snowfall at Lake Clara was about $1.4 \mathrm{~m}$.

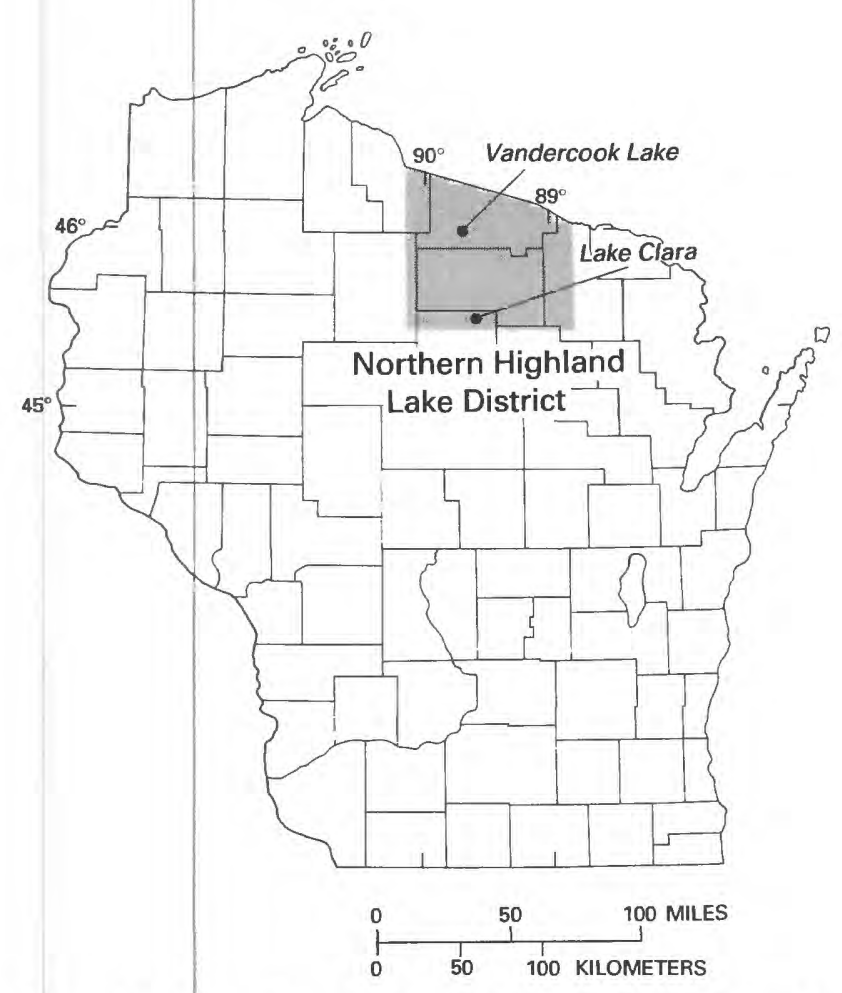

Figure 1. Locations of Lakes Clara and Vandercook in north-central Wisconsin. 
The lakes are relatively small and shallow (table 1 ). Vandercook Lake rarely exhibits even weak thermal stratification, whereas Lake Clara generally is considered to be dimictic. Ice cover commonly lasts from late November through mid-April. Physical characteristics of the lakes are summarized in table 1.

\section{Acknowledgments}

The authors would like to acknowledge the following persons: Joseph Eilers (Wisconsin Department of Natural Resources) for providing program coordination; Sam Morgan (Wisconsin Valley Improvement Company) for providing evaporation data from Rainbow Reservoir; Thomas Peterman and Hugh Rutherford, Jr. (local observers at Lakes Clara and Vandercook, respectively); and Mark Johnson and Katherine Webster (Wisconsin Department of Natural Resources) for assisting with the data collection.

\section{APPROACH}

The hydrologic budget of a typical lake is shown diagrammatically on figure 2 . The equation describing the interrelations of this budget can be written

$$
\Delta S=P-E+G I-G O+S F+O F-O,
$$

where

$\Delta S=$ change in lake storage;

$P=$ precipitation on the lake surface;

$E$ = lake evaporation;

$G I=$ ground-water inflow to the lake;

$G O=$ ground-water outflow from the lake;

$S F=$ streamflow to the lake;

$O F=$ overland flow to the lake (here defined as ephemeral channelized plus nonchannelized surface runoff); and

$\mathrm{O}=$ water lost from the lake through surface outflow.
In this report, hydrologic-budget terms are expressed as depth of water on the average lake surface during a given time increment.

Because neither Lake Clara nor Vandercook Lake receives streamflow, equation 1 reduces to

$$
\Delta S=P-E+G I-G O+O F-O .
$$

This equation describes the hydrologic budget of Lake Clara. The equation for Vandercook Lake is simpler because, as discussed later, overland flow $(O F)$ and surface outflow $(O)$ did not occur at this study area.

The approach to determining the hydrologic budgets of Lakes Clara and Vandercook was to measure each of the terms in equation 2. Because each term has associated measurement and interpretation errors (Winter, 1981), a better representation of the hydrologic budget is given by

$$
r=P-E+G I-G O+O F-O-\Delta S,
$$

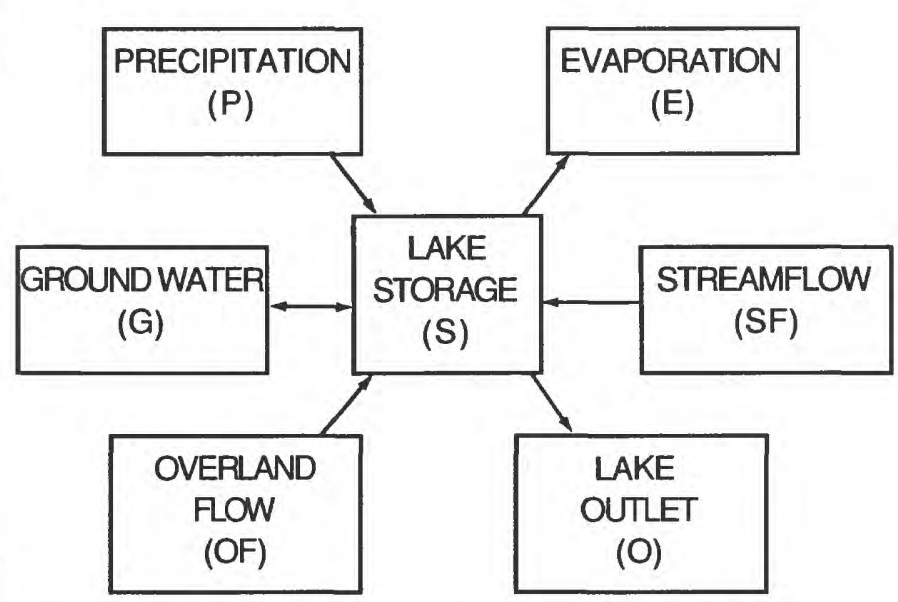

Figure 2. Interrelations among hydrologic-budget components of a typical lake.

Table 1.-Physical characteristics of Lakes Clara and Vandercook

\begin{tabular}{lcc}
\hline Characteristic & Lake Clara & Vandercook Lake \\
\hline Surface drainage basin (hectares) $^{\mathrm{a}}$ & 120 & 290 \\
Lake surface area (hectares) $^{\mathrm{b}}$ & 33 & 43 \\
Volume (cubic meters) $^{\mathrm{b}}$ & $1.6 \times 10^{6}$ & $1.9 \times 10^{6}$ \\
Mean depth (meters) $^{\mathrm{b}}$ & 4.8 & 4.4 \\
Maximum depth (meters) $^{\mathrm{b}}$ & 11.5 & 7.1 \\
\hline
\end{tabular}

${ }^{\text {a }}$ Total drainage-basin area, including the lake.

${ }^{b}$ Mean value, 1981 through 1983 water years. 


\section{METHODS}

where $r$ is defined as the net residual. The net residual includes (1) errors in the individual budget terms, and (2) inflows or outflows that have not been considered. Thus, by measuring $\Delta S, P, E, G I, G O, O F$, and $O$, an estimate of $r$ can be calculated from equation 3. This provides one criterion for determining the worth of the hydrologic budget.
Locations of the hydrologic instrumentation are shown on figure 3 for Lake Clara and on figure 4 for Vandercook Lake. The hydrologic instrumentation and information regarding the spatial and temporal distribution of data collection are summarized in table 2 .

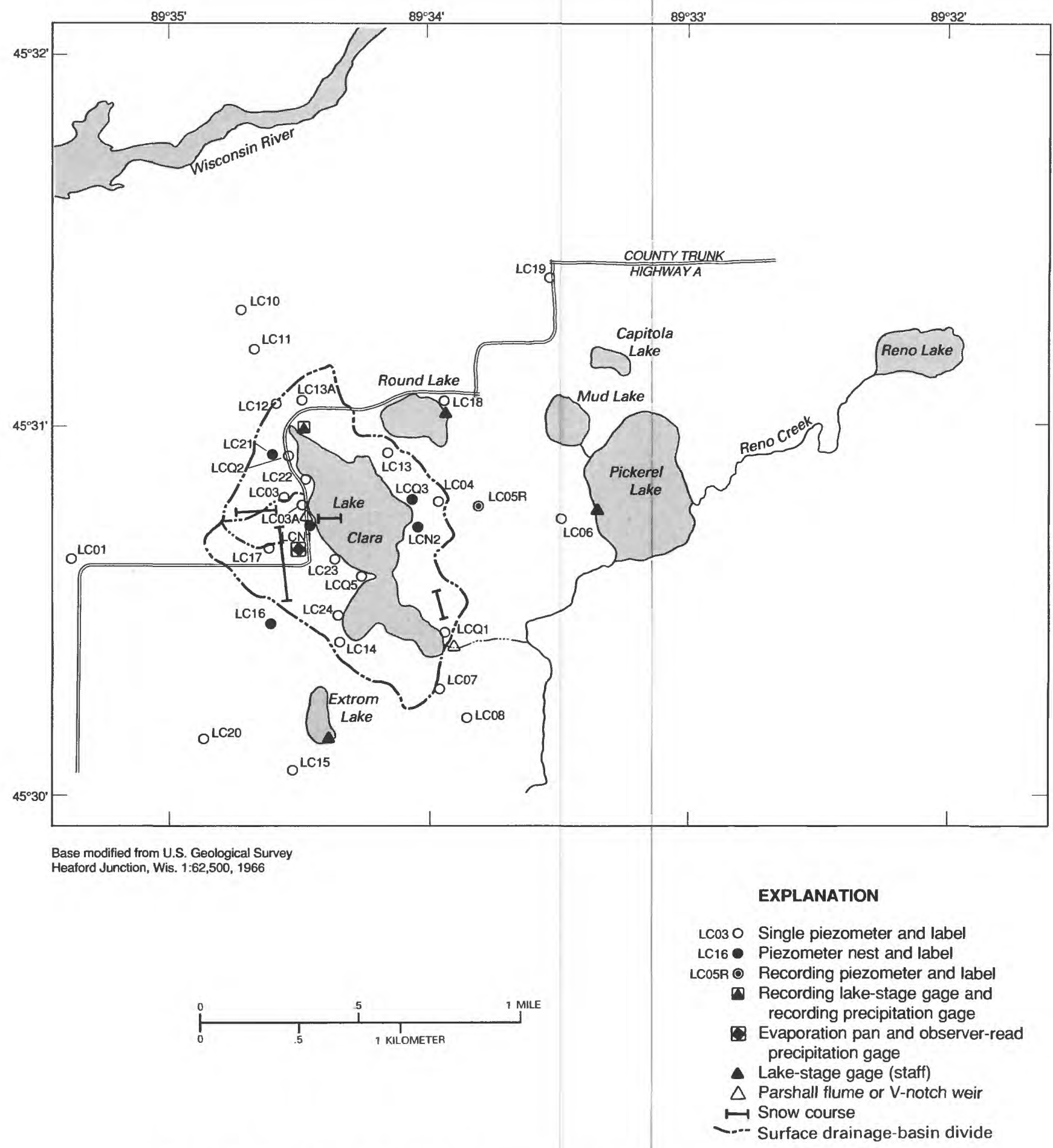

Figure 3. Locations of hydrologic instrumentation at the Lake Clara study area. 


\section{Lake Storage}

Each study lake was equipped with a bubble gage (Buchanan and Somers, 1968) for measuring lake stage year-round (figs. 3 and 4). Stage data were recorded hourly by an automatic digital recorder; the hourly values were converted to daily average values.

Stage-volume curves constructed from bathymetric maps (not shown) were used to convert the lake-stage changes to lake-volume (storage) changes. Bathymetric data were collected at Lake Clara on August 4, 1980 (J. G. Wiener, U.S. Fish and Wildlife Service, written commun.,
1983), and at Vandercook Lake on March 23, 1982 (Wisconsin Department of Natural Resources, written commun., 1983).

\section{Precipitation}

Precipitation was collected year-round in a $200-\mathrm{mm}$ diameter, observer-read gage at each study area (figs. 3 and 4). Precipitation amounts were recorded daily at about 0800 hours. Because the precipitation gages were not shielded, a totalizing anemometer was installed at the level of each gage during winter, and data from Goodison

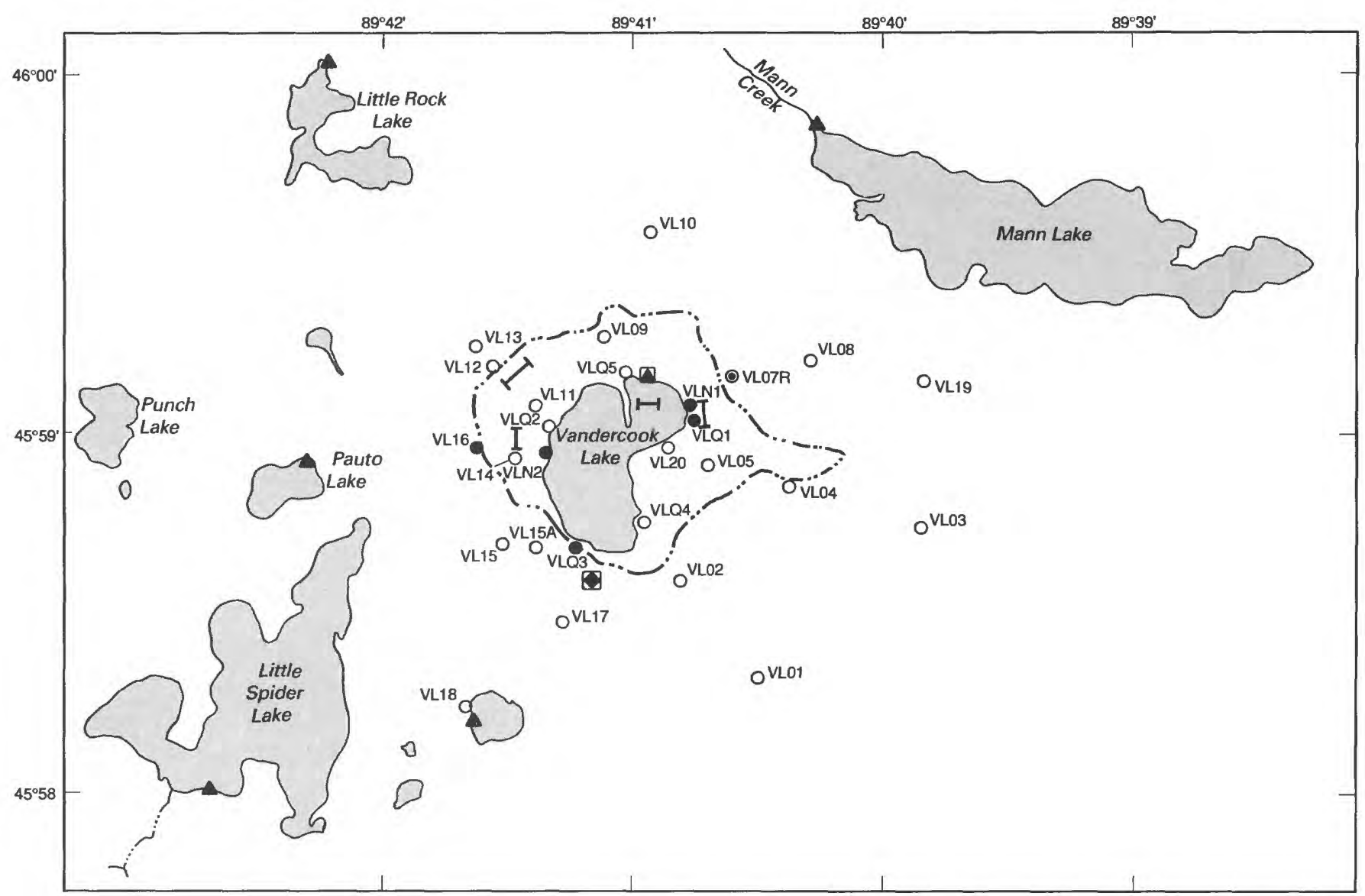

Base modified from U.S. Geological Survey Minoqua, Wis. 1:62,500, 1966

\section{EXPLANATION}

VL12O Single piezometer and label

VL16 Piezometer nest and label

VLO7R 0 Recording piezometer and label

Recording lake-stage gage and recording precipitation gage

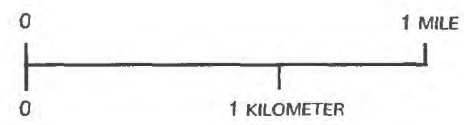

Evaporation pan and observer-read precipitation gage

- Lake-stage gage (staff)

$\longmapsto$ Snow course

-... Surface drainage-basin divide

Figure 4. Locations of hydrologic instrumentation at the Vandercook Lake study area. 
(1981, table 2) were used to correct snowfall catch for windspeed.

The amount of precipitation falling as snow was calculated as a function of air temperature measured at the observer-read gages. If both the daily maximum and daily minimum air temperatures were greater than $0^{\circ} \mathrm{C}$, precipitation was considered to be rain. If both maximum and minimum air temperatures were less than $0^{\circ} \mathrm{C}$, precipitation was considered to be snow. If the daily maximum air temperature was greater than $0^{\circ} \mathrm{C}$ and the daily minimum air temperature was less than $0^{\circ} \mathrm{C}$, the distribution of rain and snow was calculated as follows:

$$
\begin{array}{r}
\text { RAIN }=\frac{P \times T M A X}{\text { TMAX-TMIN }}, \\
\text { SNOW }=P-R A I N,
\end{array}
$$

where

$P=$ measured total daily precipitation;

TMAX = daily maximum air temperature $\left({ }^{\circ} \mathrm{C}\right)$; and

$T M I N=$ daily minimum air temperature $\left({ }^{\circ} \mathrm{C}\right)$.

This calculation algorithm accurately reproduced the actual distribution of rain and snow during the winter of 1981-82 at Round Lake in northwestern Wisconsin (Wentz and others, 1989).

A recording rain gage was located on the shore of each lake (figs. 3 and 4) to supplement data from the observer-read gage during nonfreezing periods (generally from April through October). Rainfall was collected by a 200 -mm-diameter funnel on the roof of a shelter and was transmitted to a vertical pipe in the shelter below. A float and counterweight assembly was used to measure height of water in the pipe. Rainfall amounts were re-

Table 2.-Description of instrumentation for hydrologic-budget data collection

\begin{tabular}{|c|c|c|c|c|}
\hline $\begin{array}{l}\text { Hydrologic- } \\
\text { budget } \\
\text { component }\end{array}$ & Instrumentation & $\begin{array}{c}\text { Number } \\
\text { per } \\
\text { watershed }\end{array}$ & $\begin{array}{l}\text { Frequency } \\
\text { of } \\
\text { collection }\end{array}$ & $\begin{array}{l}\text { Period } \\
\text { of } \\
\text { collection }\end{array}$ \\
\hline Lake storage & Lake-stage gage & 1 & Continuous & Year-round \\
\hline \multirow[t]{3}{*}{ Precipitation } & $\begin{array}{l}\text { 200-mm-diameter } \\
\text { gage }\end{array}$ & 1 & Continuous & $\begin{array}{c}\text { Nonfreezing } \\
\text { periods }\end{array}$ \\
\hline & $\begin{array}{l}\text { 200-mm-diameter } \\
\text { gage }\end{array}$ & 1 & Daily & Year-round \\
\hline & Snow courses & 4 & Monthly & Snow cover \\
\hline Evaporation & Class A pan & 1 & Daily & $\begin{array}{c}\text { Nonfreezing } \\
\text { periods }\end{array}$ \\
\hline \multirow[t]{3}{*}{ Ground water } & Piezometer & 1 & Continuous & Year-round \\
\hline & $\begin{array}{l}\text { Piezometers } \\
\text { (single plus } \\
\text { nests) }\end{array}$ & $\begin{array}{l}37(\mathrm{C})^{\mathrm{a}} \\
35(\mathrm{~V})^{\mathrm{a}}\end{array}$ & Monthly & Year-round \\
\hline & Lake-stage gages & $\begin{array}{l}3(\mathrm{C}) \\
5(\mathrm{~V})\end{array}$ & Monthly & $\begin{array}{l}\text { Nonfreezing } \\
\text { periods }\end{array}$ \\
\hline Overland flow & $\begin{array}{l}\text { Flume and stage } \\
\text { gage }\end{array}$ & $\begin{array}{l}1(\mathrm{C}) \\
0(\mathrm{~V})\end{array}$ & Continuous & $\begin{array}{l}\text { Nonfreezing } \\
\text { periods }\end{array}$ \\
\hline Surface outflow & $\begin{array}{l}\text { Weir and stage } \\
\text { gage }\end{array}$ & $\begin{array}{l}1(\mathrm{C}) \\
0(\mathrm{~V})\end{array}$ & Continuous & Year-round \\
\hline
\end{tabular}
[mm, millimeters]

${ }^{\mathrm{a}} \mathrm{C}=$ Lake Clara; $\mathrm{V}=$ Vandercook Lake. 
corded at 15-minute intervals, and daily total rainfall amounts were calculated.

Precipitation was not collected before May 1981 at either study area. Accordingly, monthly data for October 1980 through April 1981 were estimated for each study area from regression relations between the observerread gage and each of two nearby NWS stations. The two estimates for each month for each study area were averaged. Coefficients of determination $\left(R^{2}\right)$ for the regression relations ranged from 0.927 to 0.962 . The NWS stations used were at Rhinelander $(18 \mathrm{~km}$ northeast of Lake Clara), Rice Reservoir ( $14 \mathrm{~km}$ west of Lake Clara), Minocqua Dam (12 km south of Vandercook Lake), and Rest Lake (23 km northwest of Vandercook Lake).

Four snow courses were located at each study area (figs. 3 and 4). Three courses were established within each surface drainage basin to reflect differences in vegetation, and one course was located on lake ice. A snow course consisted of one traverse with three sampling sites. Snow depth and water content were measured with standard snow-surveying equipment (Garstka, 1964) that consists of a snow-tube-spring-scale combination having a cutter blade with an inside diameter of 38 $\mathrm{mm}$. Courses were measured monthly during periods of snow cover (typically December through April); no measurements were made during the winter of 1980-81.

\section{Evaporation}

Class A pan evaporation was measured at each lake (figs. 3 and 4) from May through October, as described by the National Oceanic and Atmospheric Administration (1972). The level of water in each pan was read daily at approximately 0800 hours by a local observer. Pan evaporation was converted to lake evaporation by applying lake/pan coefficients developed for nearby Rainbow Reservoir, as discussed later.

Evaporation (sublimation) from the lakes during periods of snow and ice cover (generally late November through mid-April) was calculated from a mass-transfer equation presented by Dunne and Leopold (1978, p. 119),

$$
E=(0.018+0.00015 U 2)(e s-e a),
$$

$$
\begin{aligned}
\text { where } & \\
E= & \text { evaporation (centimeters per day) } \\
U 2= & \text { wind speed (kilometers per day) } \\
e s= & \text { saturation vapor pressure at the temperature of } \\
& \text { the lake surface (millibars) } \text { and } \\
e a= & \text { actual vapor pressure of the air (millibars) }
\end{aligned}
$$

Saturation vapor pressure over ice or snow was calculated as a function of saturation vapor pressure over water at the same temperature (Linsley and others, 1975, p. 35), assuming that the temperature of the ice or snow was equal to air temperature. Air temperature and wind speed were measured at each lake; mean relative humidity for periods of ice cover was assumed to be 75 percent, based on data collected at similar lakes in northwestern Wisconsin during April 1982 and 1983 and NovemberDecember 1982 (Wentz and others, 1989).

During April and November, months when the lakes were frozen part of the time, a combination of the panevaporation and mass-transfer techniques was used to determine lake evaporation. November provided particular problems, because the lakes were open all or most of the month, but pan-evaporation data and lake/pan coefficients were not available. The mass-transfer technique was applied to November open-water periods by assuming values for lake temperature, air temperature, wind speed, and relative humidity. November lake evaporation is considered to be, at best, an estimate.

\section{Ground Water}

Ground-water levels were measured monthly in 37 piezometers at $\mathbf{3 0}$ sites surrounding Lake Clara (fig. 3) and in 35 piezometers at 27 sites surrounding Vandercook Lake (fig. 4). At the Lake Clara study area, single piezometers completed just below the water table were located at 24 sites; nests of two or three piezometers were located at the other six sites. Twenty-one single water-table piezometers and six piezometer nests were installed around Vandercook Lake. In piezometer nests at both study areas, the screens were separated vertically by distances from 6.7 to $22 \mathrm{~m}$, and the shallowest piezometer in the nest was completed just below the water table.

Piezometers are identified by the letters "LC" (Lake Clara) or "VL" (Vandercook Lake) followed by various combinations of two or three letters and numbers. Watertable piezometers are represented by a blank, an " $\mathrm{A}$ " (for alternate), an " $\mathrm{R}$ " (for recording), or an " $S$ " (for shallow) in the fifth position (examples: LC01, LC03A, LC05R, LCN1S). Piezometers finished considerably deeper than the water table, as in the piezometer nests, are designated by an " $M$ " (for medium) or a " $D$ " (for deep) in the fifth position (examples: LCN1M, LCN1D). Specific piezometers within a given nest are not differentiated on figures 3 and 4 . Thus, for example, the location of piezometers LCN1S, LCN1M, and LCN1D is designated on figure 3 as, simply, LCN1.

A typical piezometer installation is shown on figure 5. Most piezometers were installed by drilling a $100-\mathrm{mm}-$ diameter hole with a truck-mounted, solid-stem auger and driving 38-mm-diameter PVC pipe or 32-mm-diameter galvanized pipe to the bottom of the hole. A few lake-edge piezometers were jetted with PVC pipe. Stain- 
less-steel screens on the galvanized-pipe piezometers were $0.46 \mathrm{~m}$ long; the PVC screens were $0.91 \mathrm{~m}$ long. Piezometer depths ranged from 1.8 to $30 \mathrm{~m}$ below land surface at the Lake Clara study area; at the Vandercook Lake study area, depths ranged from 2.4 to $32 \mathrm{~m}$. The maximum depth was limited to about $32 \mathrm{~m}$ by the length of auger available.

The piezometers were not grouted (for example, with bentonite or cement) because the accurate measurement of hydraulic heads in water-table piezometers does not require this, and because only data from watertable piezometers were used to determine ground-water flow. In addition, the absence of a grouting agent eliminated a potential source of contamination in samples collected for water-quality analyses as part of other studies of the lakes.

One water-table piezometer at each study area (figs. 3 and 4) was finished with 76-mm-diameter PVC pipe and fitted with a water-level recorder attached to a float and counterweight assembly. Water levels were recorded hourly, and these data were converted to daily average values.

In addition to the piezometers, staff gages were installed at three lakes near Lake Clara (fig. 3) and at five lakes near Vandercook Lake (fig. 4); levels of these lakes were considered to be reflections of the regional water

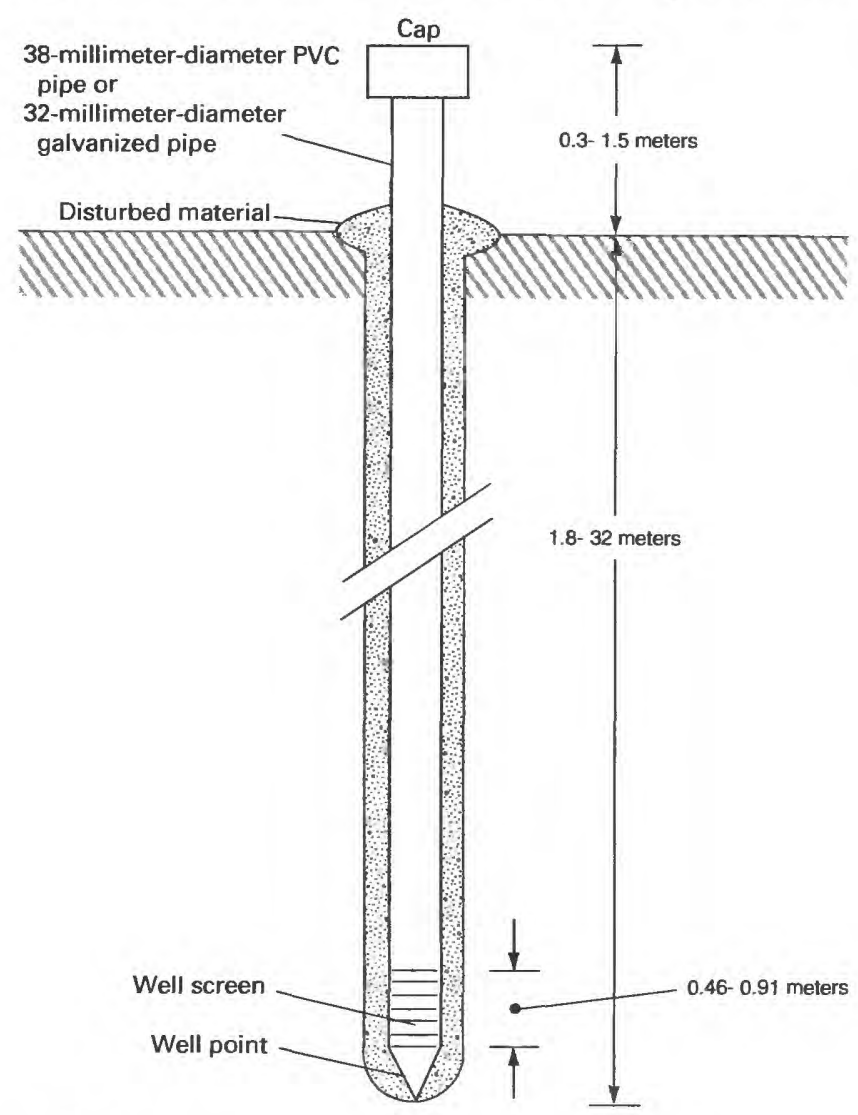

NOT TO SCALE

Figure 5. Typical piezometer installation. table. The staff gages were read monthly during nonfreezing periods when water levels in the piezometers were measured.

Measured ground-water levels and surrounding lake stages (not including the two primary study lakes) were used to construct monthly water-table-contour maps for the two study areas. Water-table altitudes were generated at a $0.13-\mathrm{km}$ grid space by using the MInimum curvature SPline (MISP) method described by Kontis and Mandle (1980); the resulting three-dimensional surfaces were plotted with existing software programs on a PR1ME 750 computer.

Slug tests were conducted on selected piezometers to determine aquifer hydraulic conductivities following the procedure putlined by Bouwer and Rice (1976). The procedure provides a method for calculating horizontal hydraulic conductivity near the piezometer screen based on the rate of water-level rise in the piezometer after sudden removal of a known volume, or "slug," of water. Rapid remoyal of the slug was accomplished by lowering a solid rod of known volume, allowing water levels to equilibrate, and then quickly removing the rod. Eight piezometers at Lake Clara and 17 at Vandercook Lake were tested. Four of the tests at Lake Clara and three at Vandercook Lake were conducted on temporary piezometers installed in the aquifer beneath the lake sediment when the lakes were frozen in March and April 1982. Tests on permanently installed piezometers were conducted in December 1981 and December 1982.

Seismic-refraction measurements were made along two lines near Lake Clara in August 1982 to determine depth to bedrock. One line, which started $150 \mathrm{~m}$ east of the lake and extended eastward for $550 \mathrm{~m}$, consisted of two slightly overlapping 12-geophone spreads. Geophones were equally spaced at 30.5 -m intervals. The second line, which started $150 \mathrm{~m}$ west of the lake and extended westward for $170 \mathrm{~m}$, consisted of a single 12-geophone spread. Geophones were equally spaced at $15.2-\mathrm{m}$ intervals. All linẹs were "reverse shot" to minimize potential interpretation errors associated with dipping bedrock surfaces (Mooney, 1980), that is, a minimum of two shots were made from each end of the spreads. The shots were provided by detonating two-component (ammonium nitrate and nitromethane) explosive in holes ranging from 1.2 to $\$ .5 \mathrm{~m}$ deep. A multichannel signal-enhancement seismograph monitored and recorded impact arrivals. The data were interpreted following the procedures outlined by Haeni (1983); a computer-analysis program was used to aid in the data interpretation (Scott and others, 1972).

The lake bottoms were probed to define the thickness, areal distribution, and, to some extent, the character of the fine-grained organic sediment. From this information, sediment-thickness maps (not shown) were constructed to assist in the analysis and interpretation of ground-water flow interacting with the lakes. 
Ground-water flow to and from the lakes was calculated by assuming that ground-water movement was vertical immediately adjacent to the lake bottom. The region beneath each lake was divided into square, vertical flow tubes, each $31.7 \mathrm{~m}$ on a side. Flow through each tube was calculated from Darcy's Law,

$$
q=K \frac{h_{s}-h_{L}}{L} A,
$$

where

$q=$ the discharge through a flow tube;

$K=$ the vertical hydraulic conductivity of the lake sediment (if present) or aquifer within the tube;

$h_{s}=$ the hydraulic head at the lower boundary surface of the tube (in the aquifer) and is equal to the water-table altitude interpolated from watertable-contour maps discussed previously;

$h_{L}=$ the hydraulic head at the upper boundary surface (lake bottom) and is equal to the measured lake stage;

$L=$ the flow-tube length and is equal to the distance between the lake bottom and the lower boundary surface; and

$A=$ the horizontal cross-sectional area of the tube (1,005 square meters).

In areas where fine-grained organic lake sediment was present, the lower boundary surface of a flow tube coincided with the sediment-aquifer interface. Where organic sediment was absent, the lower boundary surface of a flow tube was defined at a depth equal to the depth of penetration of near-shore piezometers.

Several assumptions had to be made to calculate ground-water flow to and from the lakes. First, the vertical hydraulic conductivity of the fine-grained organic sediment was assumed to be three or more orders of magnitude less than that of the aquifer material. Second, as discussed by Wentz and Rose (1989), it was necessary to specify smaller vertical hydraulic conductivities in the outflow regions of the lakes than in the inflow regions to achieve hydrologic balances at reasonable values of hydraulic conductivity for sandy materials. Initial estimates of vertical hydraulic conductivity were derived from measured horizontal conductivities by assuming anistropy ratios (horizontal:vertical) of at least 10:1 for the inflow regions and at least 100:1 for the outflow regions. These estimates were refined further in the process of determining the final hydrologic budgets, as discussed later.

Ground-water inflow and outflow rates were calculated for dates (approximately monthly) when groundwater levels and lake stages were measured. These flow rates were plotted against time, and areas under the curves were integrated to yield monthly ground-water inflows and outflows.

\section{Overland Flow}

Surface flow from a small upland watershed on the western side of Lake Clara (fig. 3) was measured with a Parshall flume (Rantz and others, 1982b) and a continuous recorder. Flows from three additional watersheds (one upland, two wetland) on the northwestern and northern sides of the lake were measured periodically with a calibrated bucket and stopwatch. Thirty instantaneous measurements were made at the latter three sites during the 3 years of study. The total overland-flow contribution to Lake Clara was estimated by (1) extending the discharge data from the gaged watershed to a similar contributing area $\mathbf{3 . 5}$ times as large (including the ungaged upland watershed), and (2) adding the flow measured for the other two ungaged (wetland) watersheds.

\section{Surface Outflow}

Surface outflow from Lake Clara was measured by continuously recording the stage behind a sharp-crested V-notch weir in the outflow channel at the southeastern end of the lake (fig. 3). The weir was rated by making periodic discharge measurements at a range of stages (Rantz and others, 1982a,b). Beaver activity in the outflow channel, immediately upstream from the weir, necessitated continual modifications to the discharge rating, thus, affecting the quality of the surface-outflow data.

\section{HYDROLOGY}

\section{Lake Stage}

Although a total lake-stage fluctuation of $0.43 \mathrm{~m}$ was recorded at Lake Clara from October 17, 1980, through September 30, 1983, the annual mean stage changed only 0.06 m during the 3 water years. Small stage increases occurred during spring following snowmelt and rainfall, but these were succeeded by summer decreases due primarily to evaporation (fig. 6). The maximum monthly stage fluctuation during the study was a $0.24-\mathrm{m}$ increase in June 1981 in response to a monthly rainfall of $240 \mathrm{~mm}$. Of this amount, $168 \mathrm{~mm}$ fell in a 23-hour period on June 13-14, causing the lake to rise $0.23 \mathrm{~m}$ by June 15 .

During the 1981 and 1982 water years, stage changes at Vandercook Lake were similar to those at Lake Clara. Summer declines due to evaporation followed spring increases from snowmelt and rainfall, but the annual mean stage remained fairly constant (fig. 7). However, from September 1982 to the end of the study, the level of Vandercook Lake gradually increased about $0.2 \mathrm{~m}$. The increase probably was caused by above-normal precipitation that occurred during the 1982 and 1983 water years (see following discussion under "Precipitation"). The total lake-stage fluctuation from November 5,1980 , through September 30,1983 , was $0.33 \mathrm{~m}$. The maximum monthly fluctuation of $0.14 \mathrm{~m}$ occurred in April 1982 as the lake level rose in response to snowmelt and a monthly 
precipitation of $153 \mathrm{~mm}$. The storm of June 13-14, 1981, produced $112 \mathrm{~mm}$ of rain in a 22-hour period and caused the stage to rise $0.10 \mathrm{~m}$ by June 15 .

At both lakes, the range of stages recorded during the 3 years of study encompassed the lake stage determined for the date of bathymetric survey. Thus the stagearea and stage-volume curves (fig. 8) are representative of the conditions that were observed. The stage-volume curves were extrapolated a maximum of $0.36 \mathrm{~m}$ at Lake Clara and $0.31 \mathrm{~m}$ at Vandercook Lake to convert stage changes to storage changes.

\section{Precipitation}

Precipitation measured in the observer-read gages has been summarized by water year and compared to long-term normal precipitation at nearby NWS stations (table 3). The 1951-80 calendar-year average precipitation near Lake Clara, based on the Rhinelander and Rice Reservoir NWS stations, was $794 \mathrm{~mm}$; the average for the same period near Vandercook Lake, based on the Minocqua Dam and Rest Lake NWS stations, was 834 $\mathrm{mm}$. Relative to these values, precipitation at Lake Clara was near normal during the first 2 years of study and was

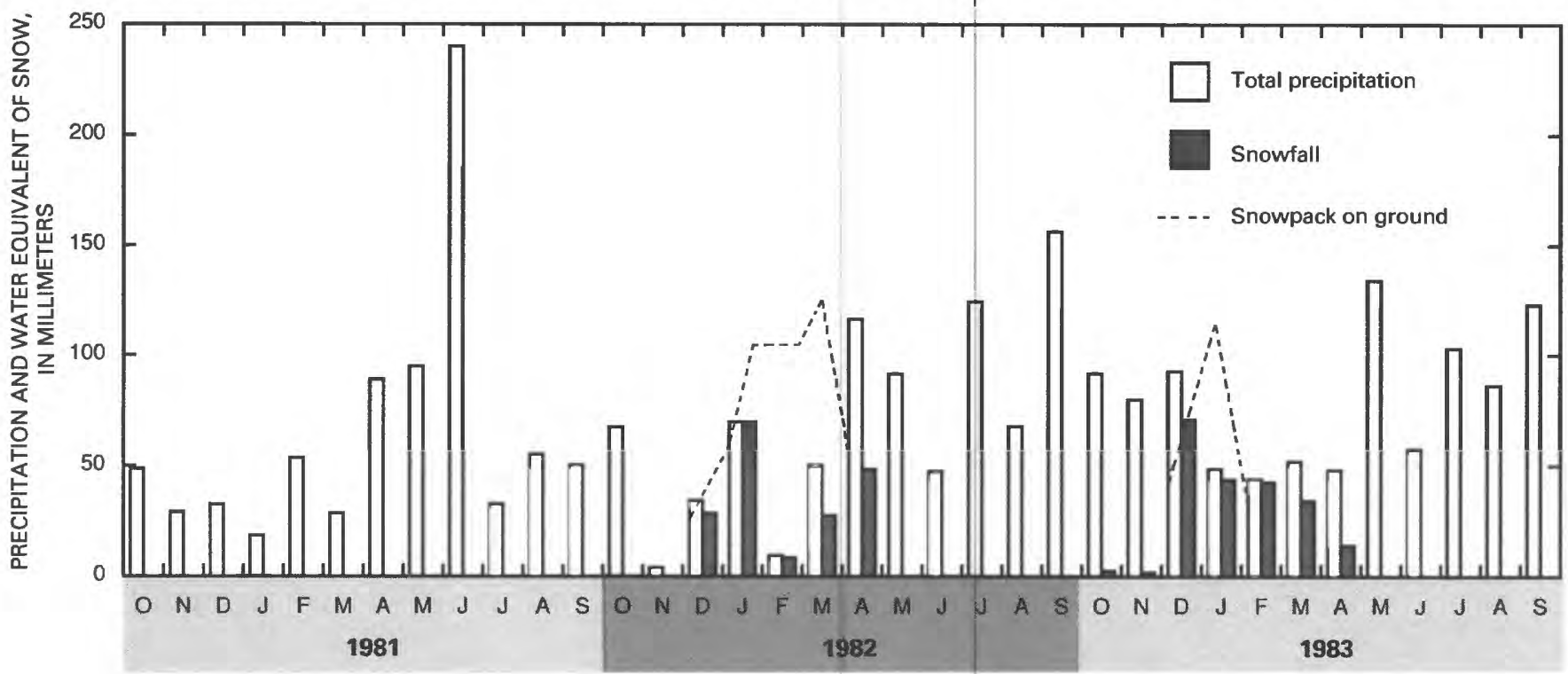

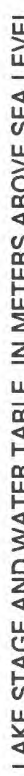
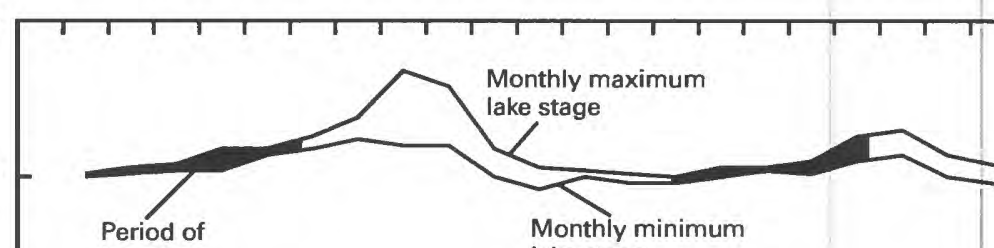

ice cover

Monthly minimum

lake stage

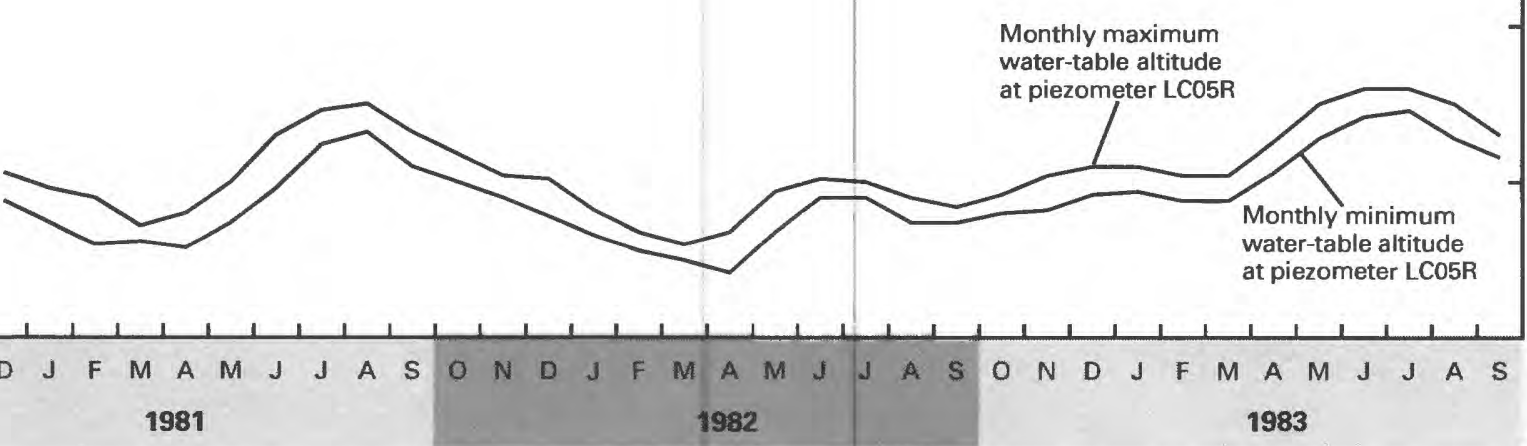

WATER YEAR

Figure 6. Precipitation, snowpack, lake stage, and water table at Lake Clara. 
21 percent greater than normal during the third year. At Vandercook Lake, precipitation was 16 percent below normal during the first year, and 17 and 18 percent above normal during the second and third years, respectively.

The monthly distributions of precipitation at Lake Clara (fig. 6) and Vandercook Lake (fig. 7) were similar, with relatively dry periods from late fall to early spring and wetter weather the rest of the year. Most of the precipitation (63 to 76 percent) fell as rain from May through October.

Areal variations in rainfall near the study lakes were minimal. For the summers of 1981 and 1982, regression relations between daily rainfall catch from the observerread and recording gages produced coefficients that were similar and about equal to unity; regression constants were near zero (table 4). The observer-read and recording gages were located $0.6 \mathrm{~km}$ apart at Lake Clara (fig. 3) and $1.1 \mathrm{~km}$ apart at Vandercook Lake (fig. 4).

Annual snowfall was 22 percent of total precipitation at Lake Clara and 24 to 29 percent at Vandercook Lake during the last 2 water years of study. Snow accumulation began in November 1981 at both study areas and peaked during March 1982 (figs. 6 and 7). The snow melted by late April 1982. The water equivalent of the snowpack

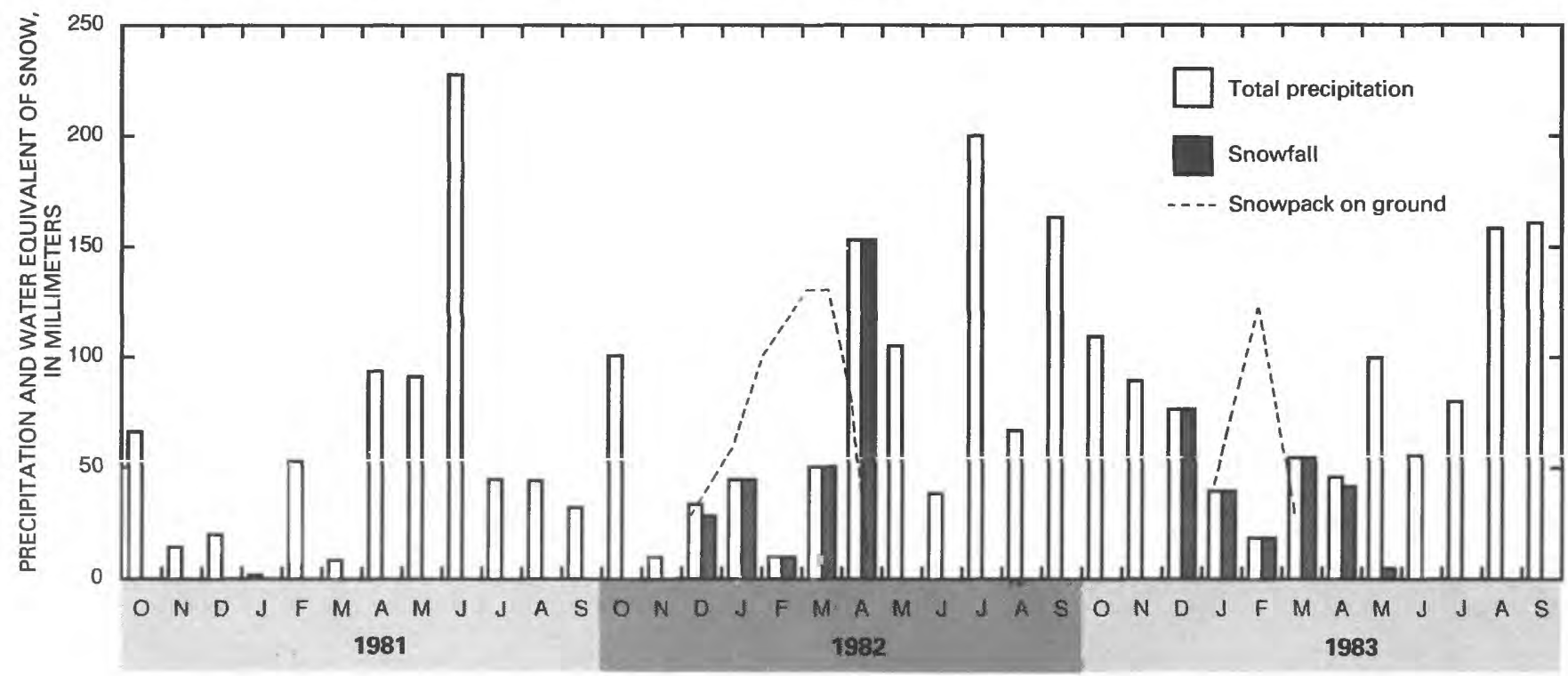

焉

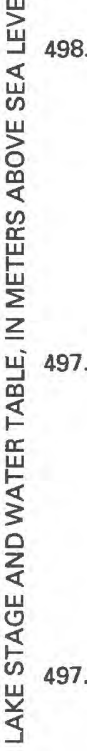
O

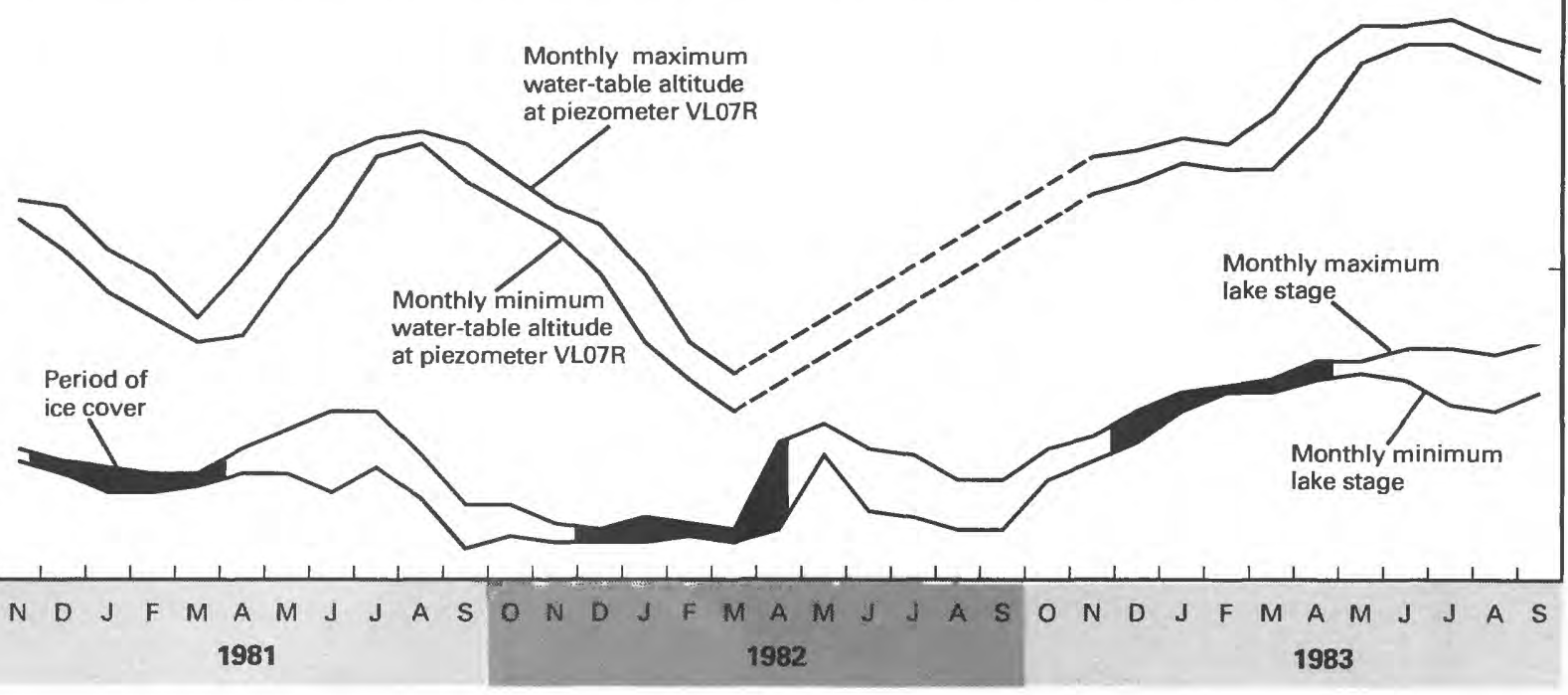

WATER YEAR

Figure 7. Precipitation, snowpack, lake stage, and water table at Vandercook Lake. (Dashed lines for water-table altitude represent missing data.) 
reached $130 \mathrm{~mm}$ in the Lake Clara watershed; a peak of $132 \mathrm{~mm}$ was recorded in the Vandercook Lake watershed. During the winter of 1982-83, the snowpack water equivalent peaked in February, approximately 1 month earlier than during the winter of 1981-82. Peak water equivalent was $118 \mathrm{~mm}$ at Lake Clara and $126 \mathrm{~mm}$ at Vandercook Lake. Snowmelt was complete at both study areas by the beginning of April 1983, about 1 month earlier than during the previous winter.

Average peak water equivalent of snowpack in the Lake Clara watershed was not statistically different between the two winters of measurements, based on a t-test (Rickmers and Todd, 1967) at an alpha $(\alpha)$ probability of 0.05 . This also was true of the Vandercook Lake watershed. In addition, average peak water equivalent of snowpack did not differ between the two watersheds during either winter.
Water equivalent of snow on lake ice at Lakes Clara
Vandercook during the 1981-82 and 1982-83 winters was significantly less $(\alpha=0.05)$ than under various vegetative covers in the watersheds. A maximum water equivalent of $51 \mathrm{~mm}$ was measured on the ice at Lake Clara in late March 1982, and a maximum of $54 \mathrm{~mm}$ was measured on the ice at Vandercook Lake at the same time. During the second winter, maximum water equivalents of 29 and $44 \mathrm{~mm}$ at Lakes Clara and Vandercook, respectively, were measured in early February. At Lake Clara, the water equivalent of snow on lake ice ranged from 16 to 39 percent of the watershed values during the winter of 1981-82; a range of 25 to 57 percent was recorded during 1982-83. Percentages at Vandercook Lake ranged from 21 to 60 during the 1981-82 winter and from 35 to 70 during 1982-83. Some of the snow falling on the lakes probably was incorporated into the

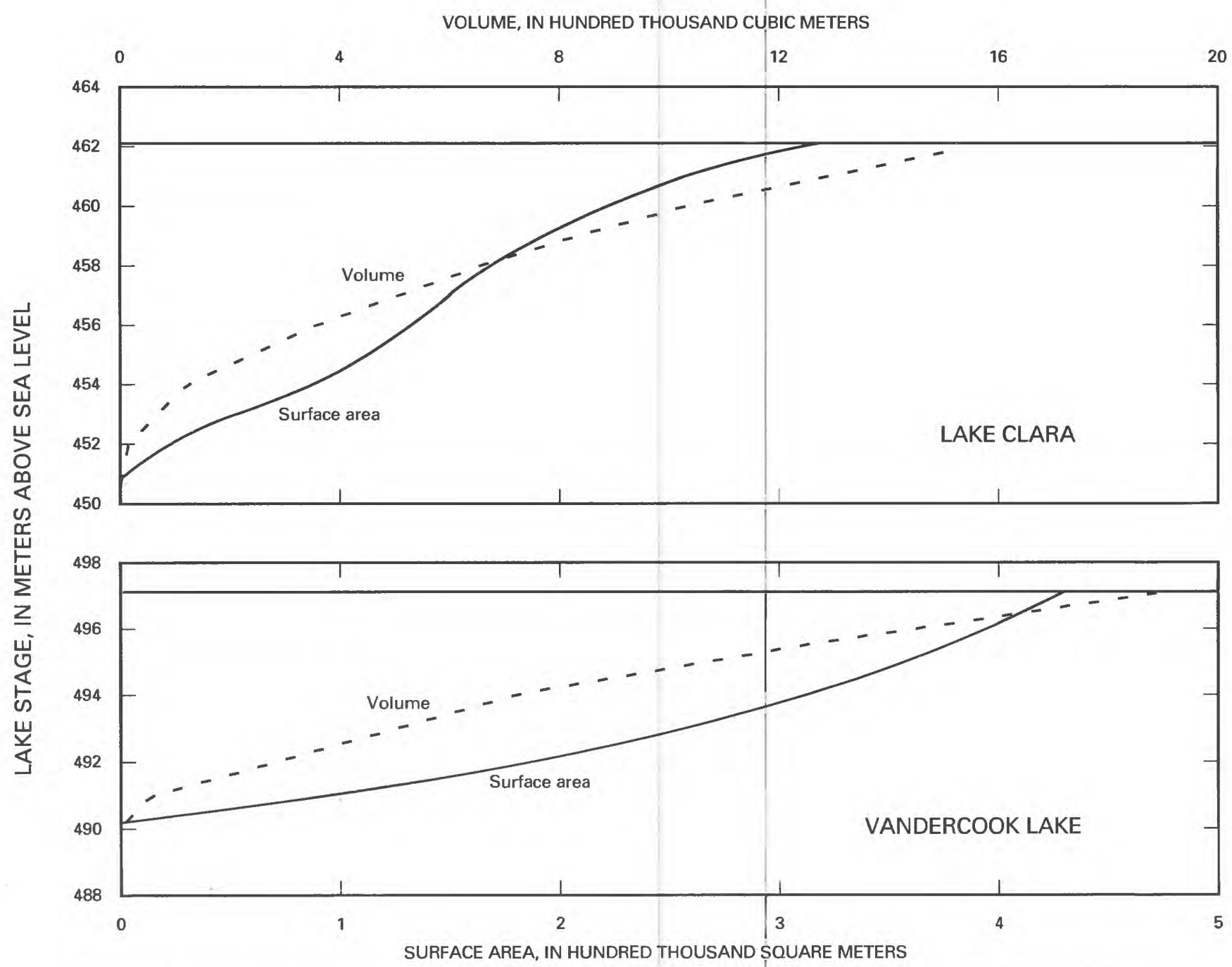

Figure 8. Stage-area and stage-volume curves for Lake Clara (August 4, 1980) and Vandercook Lake (March 23, 1982).

[Data for Lake Clara are from J. G. Wiener (U.S. Fish and Wildlife Service, written commun., 1983); data for Vandercook Lake are from Wisconsin Department of Natural Resources (written commun., 1983).] 
lake-ice cover (Gow and Langston, 1977; Gow and Govoni, 1983). Also, the open exposure of the frozen lake surface apparently allowed more ablation of the snow cover, particularly by sublimation and by wind removal.

\section{Evaporation}

Although May through October pan evaporation for a given year at Lake Clara was always numerically greater than at Vandercook Lake (table 5), mean values for the 3 years of study $(661 \mathrm{~mm}$ at Lake Clara and $626 \mathrm{~mm}$ at Vandercook Lake) were not statistically different between the two areas $(\alpha=0.05)$. Data presented by Farnsworth and others (1982, Map 1) indicate that the average May through October pan evaporation, based on the period 1956-70, should be about $705 \mathrm{~mm}$ at Lake Clara and $630 \mathrm{~mm}$ at Vandercook Lake. Mean measured pan evaporation at the two study areas did not differ significantly $(\alpha=0.05)$ from these values.

Pan evaporation at the two study areas was converted to lake evaporation with lake/pan coefficients developed from data collected at Rainbow Reservoir, which is $19 \mathrm{~km}$ southeast of Vandercook Lake and $35 \mathrm{~km}$ north of Lake Clara. The NWS operated a Class A evaporation pan at the reservoir, and the Wisconsin Valley Improvement Company measured daily evaporation in a modified pan, which floated in a sheltered bay of the reservoir. The lake pan was designed so that radiation and conduction of energy through the base and sides of the pan were small, and the water temperature in the pan approximated the lake temperature. Unfortunately, because of its location, the floating pan may not have been subjected to wind conditions and surface-water temperatures that were representative of most of the reservoir. However, for the

Table 3.-Annual precipitation

\begin{tabular}{|c|c|c|c|c|}
\hline Study area & $\begin{array}{l}\text { Water } \\
\text { year }\end{array}$ & $\begin{array}{l}\text { Precipitation } \\
\text { (millimeters) }\end{array}$ & $\begin{array}{l}\text { Departure fror } \\
\text { (millimeters) }\end{array}$ & $\begin{array}{r}\text { m normal }^{\mathrm{b}} \\
\text { (percent) }\end{array}$ \\
\hline \multirow[t]{3}{*}{ Lake Clara } & 1981 & 774 & -20 & -3 \\
\hline & 1982 & 840 & 46 & 6 \\
\hline & 1983 & 962 & 168 & 21 \\
\hline \multirow[t]{3}{*}{ Vandercook Lake } & 1981 & 697 & -137 & -16 \\
\hline & 1982 & 976 & 142 & 17 \\
\hline & 1983 & 988 & 154 & 18 \\
\hline
\end{tabular}

Table 4.- Regression relations between daily rainfall catch in observer-read and recording gages [observer-read gage $(\mathrm{mm})=[\mathrm{b} \times$ recording gage $(\mathrm{mm})]+a$ ]

[mm,millimeters]

\begin{tabular}{lcccccc}
\hline Study area & Period & $\begin{array}{c}\text { Regression } \\
\text { constant } \\
\text { (a) }\end{array}$ & $\begin{array}{c}\text { Regression } \\
\text { coefficient } \\
(\mathbf{b})\end{array}$ & $\begin{array}{c}\text { Coefficient of } \\
\text { determination } \\
\left(\mathbf{R}^{2}\right)\end{array}$ & $\begin{array}{c}\text { Number of } \\
\text { data pairs }\end{array}$ & $\begin{array}{c}\text { Approximate } \\
\text { range of } \\
\text { values } \\
(\mathbf{m m})\end{array}$ \\
\hline Lake Clara & Apr. 22-Oct. 21, 1981 & 0.11 & 0.93 & 0.98 & 97 & $0-60$ \\
& Apr. 29-Nov. 6, 1982 & .009 & .95 & .96 & 111 & $0-60$ \\
Vandercook Lake & Apr. 25-Oct. 28, 1981 & .07 & 1.09 & .94 & 116 & $0-45$ \\
& June 11-Oct. 28, 1982 & -.36 & .98 & .90 & 100 & $0-60$ \\
\hline
\end{tabular}


present analysis, evaporation from the floating pan was assumed to be the same as lake evaporation.

Monthly lake/pan coefficients for Rainbow Reservoir, calculated as the quotient of total monthly evaporation from the floating pan divided by total monthly evaporation from the Class $A$ pan, are summarized on figure 9 for the period 1971-83. The mean coeffi-

Table 5.-Pan evaporation

\begin{tabular}{lcc}
\hline Study area & Period & $\begin{array}{c}\text { Pan evaporation } \\
\text { (millimeters) }\end{array}$ \\
\hline Lake Clara & May-Oct. 1981 & 623 \\
& May-Oct. 1982 & 679 \\
& May-Oct. 1983 & 680 \\
Vandercook Lake & May-Oct. 1981 & 604 \\
& May-Oct. 1982 & 629 \\
& May-Oct. 1983 & 644 \\
\hline
\end{tabular}

cient increased slightly from May through August, and variability remained reasonably constant during these months. Both the mean coefficient and its variability increased in September and October. The average May through October coefficient for the $1971-83$ period was 0.89 . Although the previous discussion emphasizes mean monthly lake/pan coefficients, the actual coefficient for a given month and year was used to calculate lake evaporation from pan evaporation for Lakes Clara and Vandercook during open-water periods from May through October.

Annual lake evaporation, as calculated from a combination of lake/pan coefficients and equation 6, ranged from 643 to $684 \mathrm{~mm}$ at Lake Clara and from 585 to 624 mmat Vandercook Lake. Monthly distributions of evaporation were quite similar for the two lakes (fig. 10). Most of the evaporation occurred from May through October, whereas evaporation during periods of ice cover was small (4 to 6 percent).

\section{Ground Water}

Water-table trends generally were similar to those for lake stage at the two study areas. The long-term water

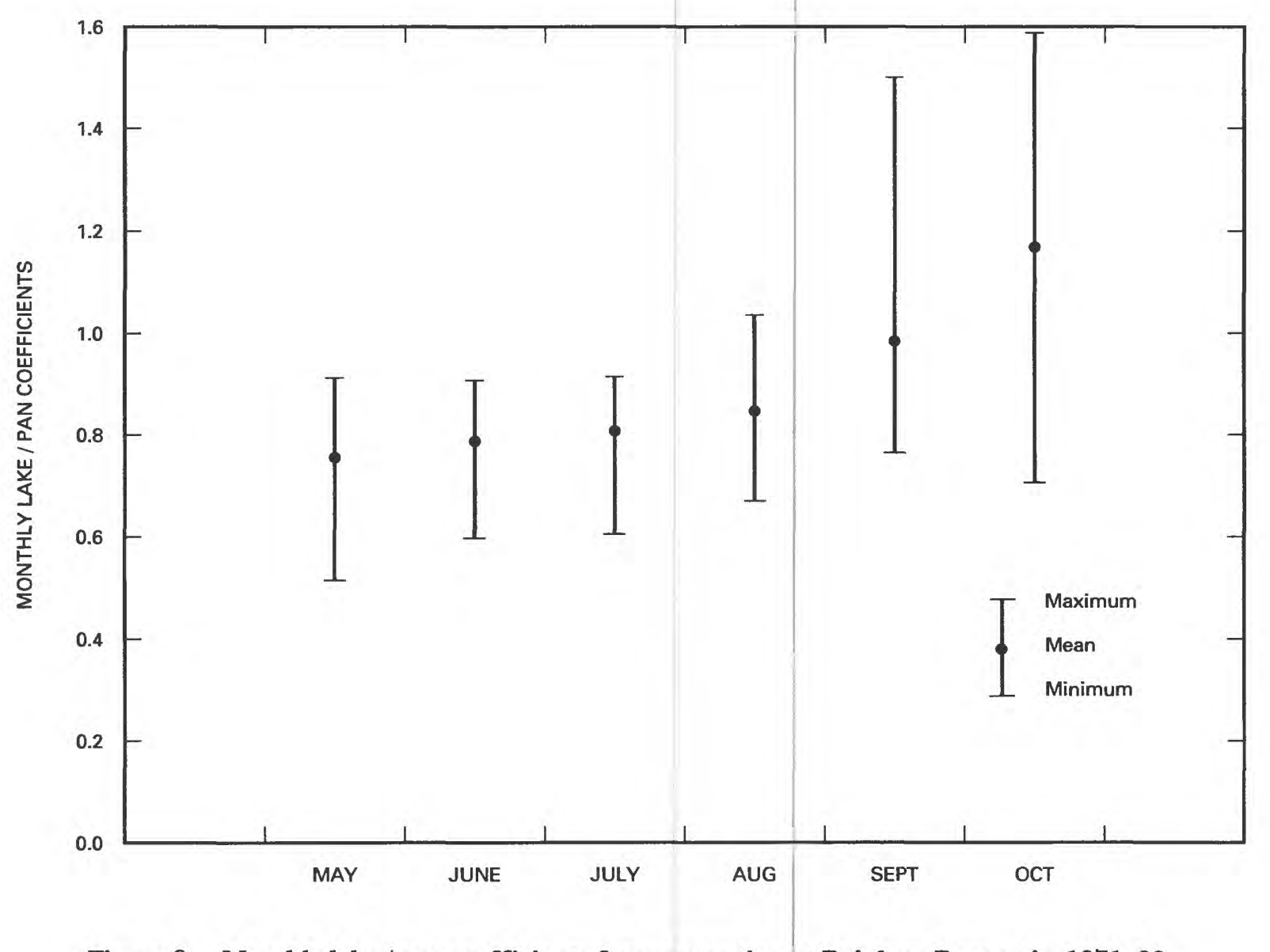

Figure 9. Monthly lake/pan coefficients for evaporation at Rainbow Reservoir, 1971-83. 
table measured at piezometer LC05R changed little during the 3-year study (fig. 6), whereas at piezometer VL07R, a rise of about $0.3 \mathrm{~m}$ was measured during the last year (fig. 7). Total water-table fluctuations in 25 piezometers averaged $0.73 \mathrm{~m}$ at the Lake Clara study area and $0.57 \mathrm{~m}$ at the Vandercook Lake study area during the 3year study, and were significantly greater at the Lake Clara study area $(\alpha=0.05)$.

Calculation of horizontal hydraulic conductivities from slug tests at the two study areas (table 6) yielded values that are similar, reasonably uniform, and typical of clean sands (Freeze and Cherry, 1979). Comparison of the hydraulic conductivities at the two study areas indicated no significant difference $(\alpha=0.05)$.

At Lake Clara, glacial drift overlies Precambrian bedrock that is comprised of mafic, intermediate, and felsic metavolcanic rocks with subordinate metasedimentary rocks (Mudrey and others, 1982). Drift thickness measured east and west of the lake ranged from 43 to $55 \mathrm{~m}$; saturated thickness ranged from 29 to $47 \mathrm{~m}$. The glacial drift at Vandercook Lake overlies Precambrian bedrock that is poorly defined, but probably is comprised of igneous and metamorphic rocks (Okwueze, 1983). On the basis of seismic-refraction data presented by Okwueze (1983), the thickness of the drift was estimated to be 50 to $55 \mathrm{~m}$; saturated thickness was approximately $40 \mathrm{~m}$.

The water-table-contour maps indicate that during the 1981-83 water years, Lake Clara was a recharge lake with a somewhat localized flow system (fig. 11). Water from the lake recharged the ground-water system and flowed predominantly away from the lake. Only a small area in the northwest part of Lake Clara received groundwater inflow during the study. At piezometer LC22, the water table was consistently upgradient from the lake; at piezometer LCQ2, ground-water inflow to the lake was seasonal, occurring primarily in the spring following snowmelt (fig. 12).

In contrast to Lake Clara, Vandercook Lake was a ground-water flow-through lake located in a regional flow system (fig. 13) during the 1981-83 water years. Ground water in the regional system moved from east to west, but only the northeastern basin of the lake received ground-water inflow during the study. The water level in
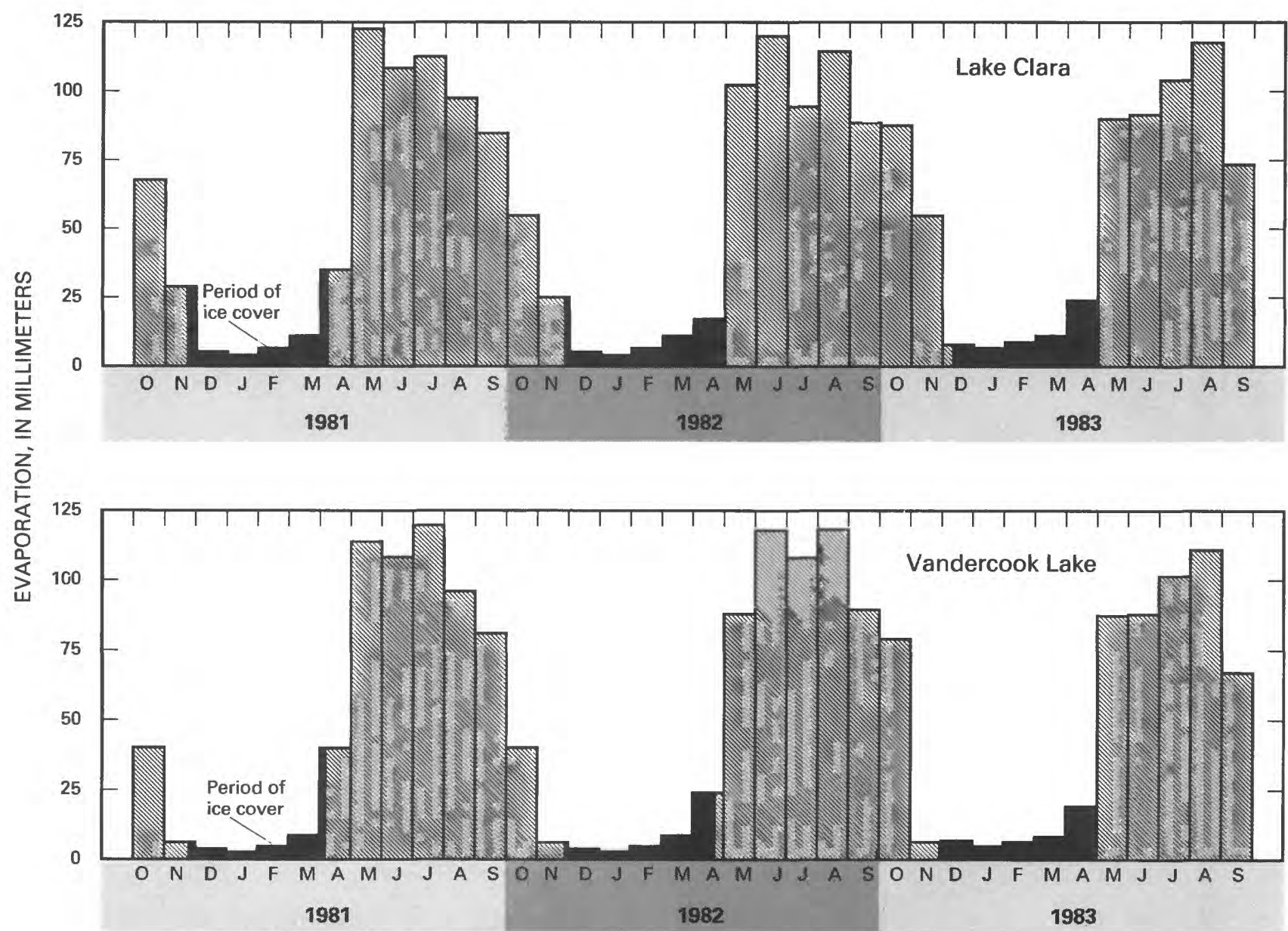

WATER YEAR

Figure 10. Monthly evaporation at Lakes Clara and Vandercook. 
piezometer VLN1S was always upgradient from the lake, whereas levels in piezometers VL20 and VLQ4 were consistently downgradient from the lake (fig. 14).

The patterns of monthly net ground-water flow (inflow minus outflow) at Lakes Clara and Vandercook were similar (fig. 15). During most of the study, net flow was from the lakes to the ground-water systems. Only during summer and fall of 1981 and during spring and summer of 1983 was there any net ground-water inflow to the lakes. At these times, gradients toward the lakes were maximal, whereas gradients away from the lakes were minimal.

Monthly ground-water inflows and outflows (not shown) were smaller at Lake Clara than at Vandercook

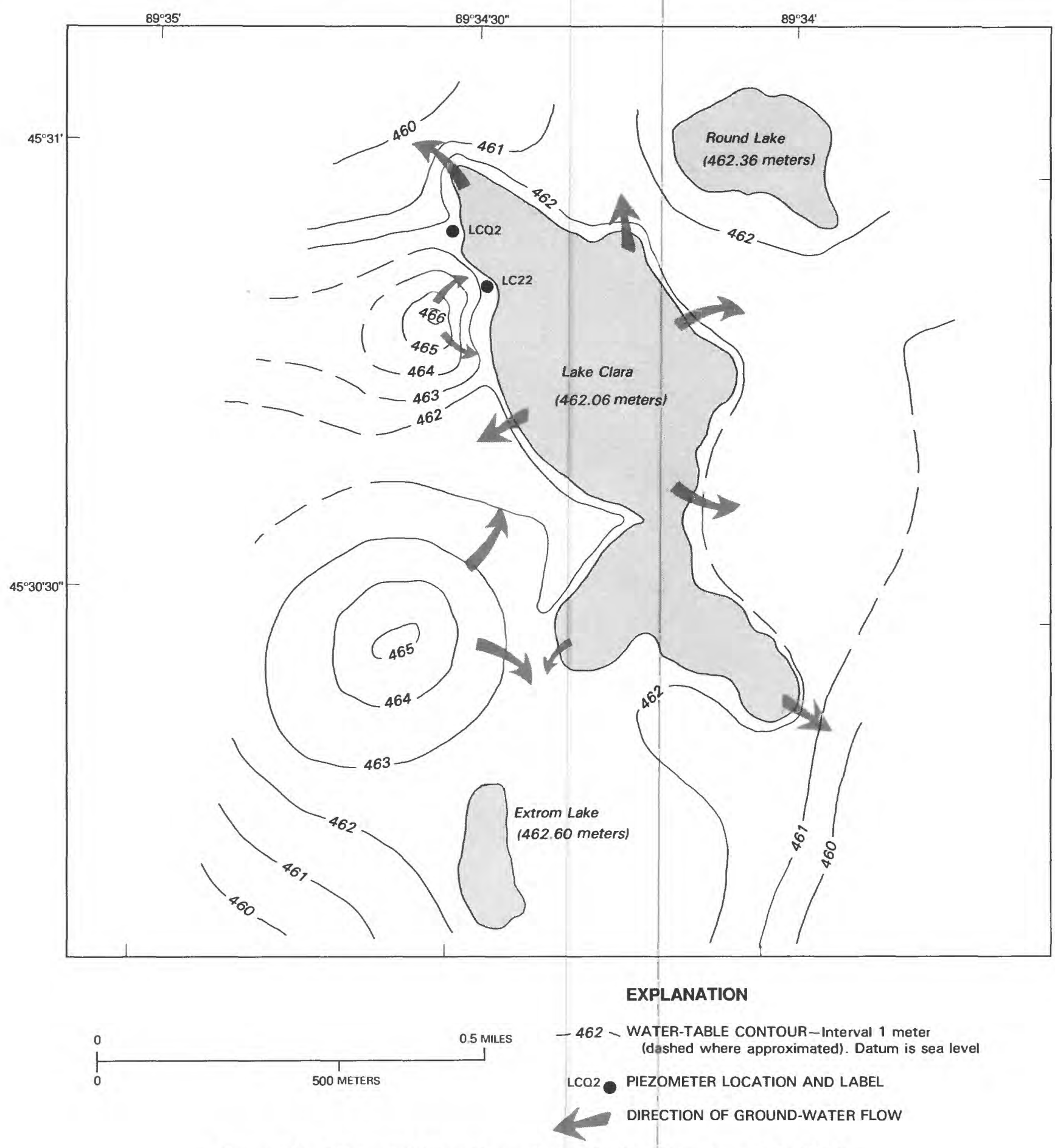

Figure 11. Water-table configuration at Lake Clara, June 3-4, 1982. 
Lake. Monthly ground-water inflow to Lake Clara varied from 0 to $21 \mathrm{~mm}$, whereas outflow ranged from 4 to 26 $\mathrm{mm}$. At Vandercook Lake, monthly ground-water inflow was 1 to $47 \mathrm{~mm}$, and outflow was 17 to $48 \mathrm{~mm}$.

\section{Overland Flow}

Overland flow was not observed at Vandercook Lake during the 3-year study, nor was there any evidence (for example, rill channels) of overland flow. At Lake Clara, however, overland flow was a measurable input to the water balance (fig. 16). The sources of overland flow were the northern and western areas of the watershed where low-permeability till impeded infiltration of snowmelt runoff and heavy summer rain.

\section{Surface Outflow}

Vandercook Lake has no surface outlet. Surface outflow from Lake Clara (fig. 16) was intermittent and followed spring snowmelt and periods of considerable rain. This pattern is similar to that found for overland flow contributions to the lake.

\section{Hydrologic Budgets}

Annual hydrologic budgets were derived by performing calculations on a monthly basis and summing the values by water year. The 1981-82 water years were selected as a calibration period, and residuals in the annual hydrologic budgets were minimized by adjusting

Table 6.-Horizontal hydraulic conductivity calculated from shug tests

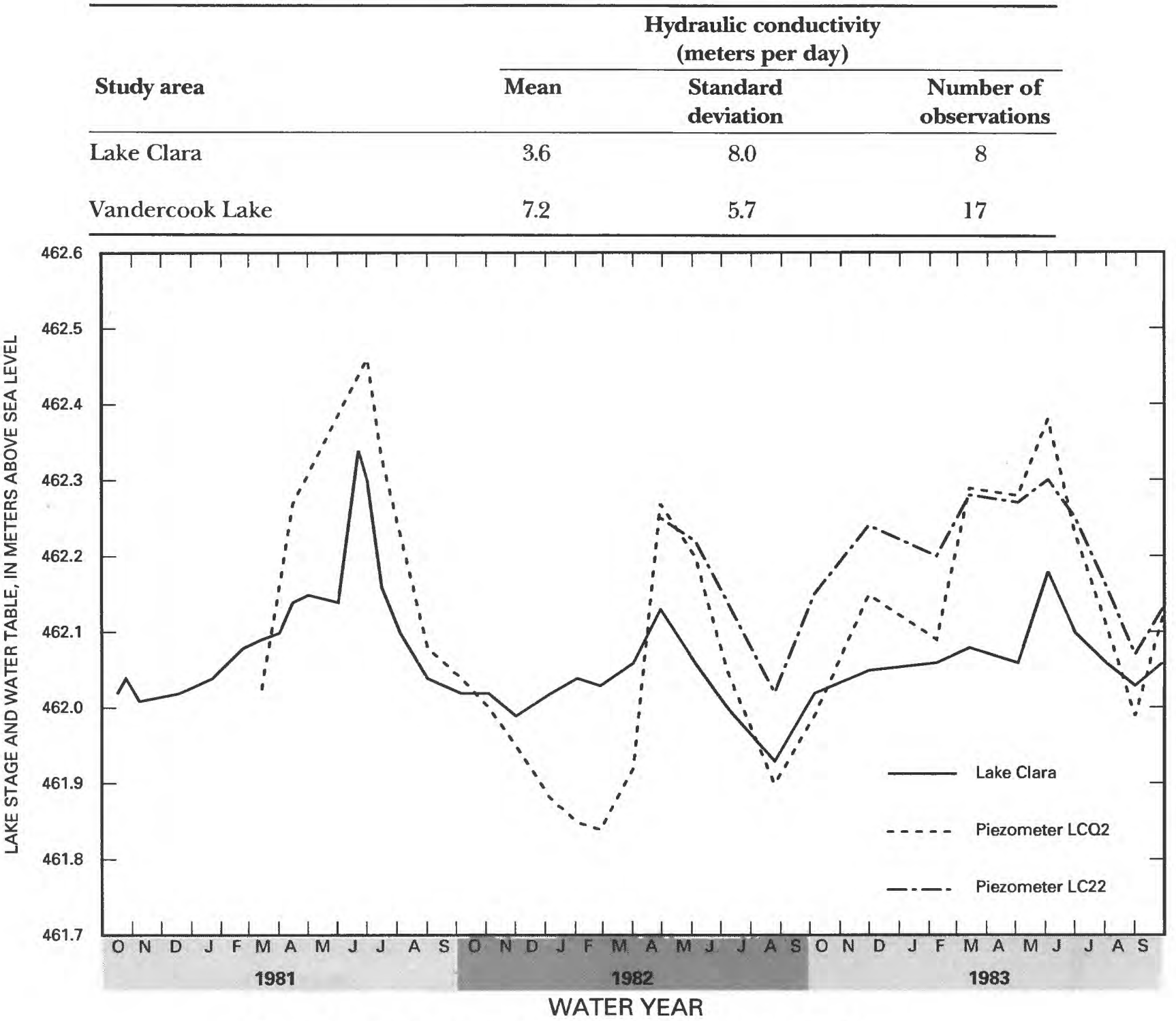

Figure 12. Lake stage and adjacent water table at Lake Clara.

(See figure 11 for piezometer locations.) 
18

vertical hydraulic conductivities (as discussed previously) to vary ground-water inflow and outflow. Final values of vertical hydraulic conductivity were $0.24 \mathrm{~m} / \mathrm{d}$ (meter per day) for inflow to Lake Clara, $0.32 \mathrm{~m} / \mathrm{d}$ for inflow to Vandercook Lake, and $0.037 \mathrm{~m} / \mathrm{d}$ for outflow from both lakes. The procedure was verified by using the calibrated conductivities to compute the hydrologic budgets for the 1983 water year.
Annual hydrologic budgets are presented in table 7 for Lakes Clara and Vandercook. The net residual $(r)$ was calculated from equation 3 , and can be viewed as the difference between estimated change in storage ( $P-E+G I-$ $G O+O F-O)$ and measured change in storage $(\triangle S)$. Thus, an overestimated change in storage is expressed as a positive residual. Percent residual is operationally defined as

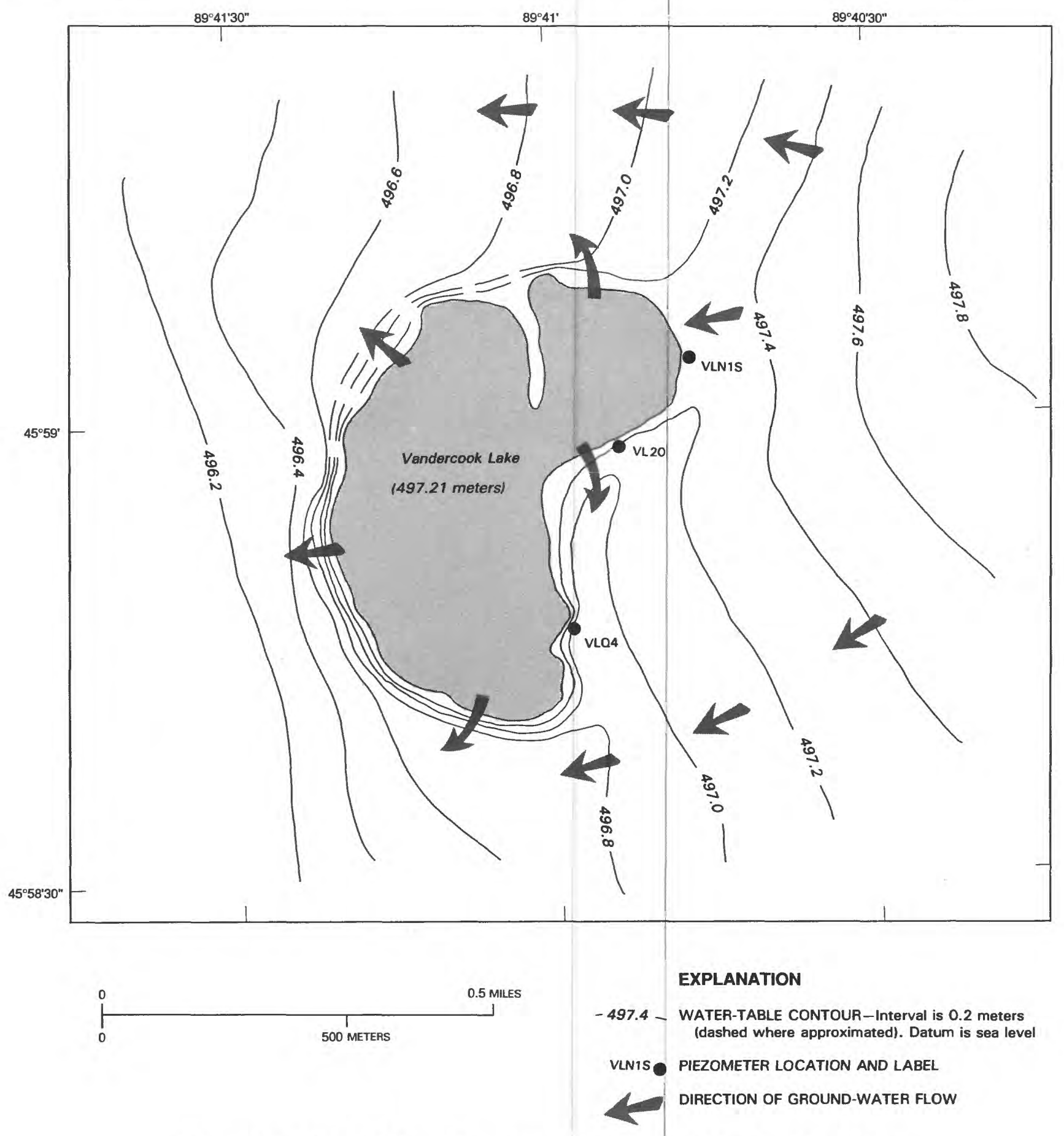

Figure 13. Water-table configuration at Vandercook Lake, June 1-2, 1982. 


$$
r(\text { percent })=\frac{r}{\frac{(\text { inflow }+ \text { outflow }) / 2}{\frac{2 r}{(P+G I+O F+E+G O+O)}} \times 100=} \times 100,
$$

and is expressed relative to the average of the inflow and outflow rates.

Absolute values of residuals in the annual hydrologic budgets were larger for Lake Clara than for Vandercook Lake. In addition, absolute residuals for Lake Clara often were larger than individual terms in the hydrologic budgets, whereas absolute residuals for Vandercook Lake were always smaller than other hydrologic-budget terms. The generally poorer residuals for Lake Clara may have resulted partly from problems in determining budget contributions from the two additional terms, overland flow and surface outflow, at this study area. A discussion of errors contributing to residuals in lake hydrologic budgets is given by Winter (1981).

The hydrologic budgets show that inflow to both lakes was dominated by precipitation, whereas outflow occurred primarily through evaporation (table 8). During the 3 years of study, from 77 to 91 percent of the annual total inflow to Lake Clara resulted from precipitation; losses by evaporation were from 59 to 75 percent. At
Vandercook Lake, precipitation contributed from 79 to 87 percent of the total annual inflow, whereas from 59 to 63 percent of the outflow was evaporation.

Hydraulic or water residence time ( $H R T)$ - the average amount of time a parcel of water spends in the lakewas calculated by dividing lake volume by outflow rate:

$$
H R T=\frac{0.1 \bar{V}}{\overline{S A}(E+G O+O)},
$$

where

$\bar{V}=$ the annual average lake volume (cubic meters), $\overline{S A}=$ the annual average surface area (hectares).

Chemical residence time (CRT) - the average amount of time a specific chemical constituent spends in the lakewas calculated as

$$
C R T=\frac{0.1 \bar{V}}{\overline{S A}(G O+O)},
$$

assuming that evaporation is pure water and that dissolved materials leave the lake only via the ground-water or surface-outflow components. This is strictly true only for conservative substances. Chemical residence times for materials removed by biological, chemical, and(or)

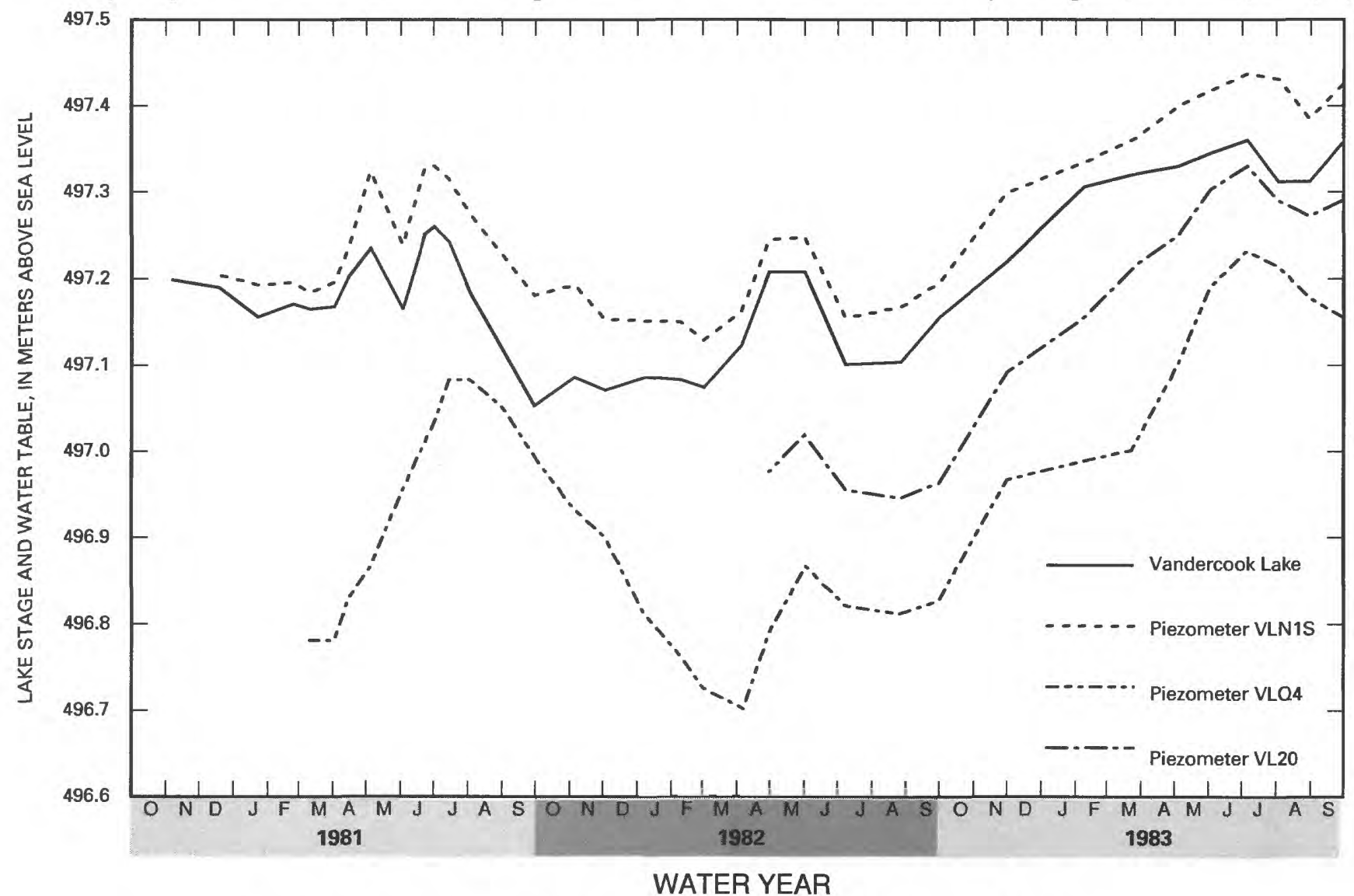

Figure 14. Lake stage and adjacent water table at Vandercook Lake. (See figure 13 for piezometer locations.) 
Table 7.-Annual hydrologic budgets

$[-$, nonexistent; $P$, precipitation; $E$, evaporation; $G I$, ground-water inflow; $G O$, ground-water outflow; $O F$, overland flow; $O$ surface outflow; $\Delta S$, storage change; $r$, residual]

\begin{tabular}{lcccccc|ccccc}
\hline & & \multicolumn{7}{c|}{ Millimeters of water on lake surface } & \\
\cline { 2 - 9 } Lake & $\begin{array}{c}\text { Water } \\
\text { year }\end{array}$ & $\boldsymbol{P}$ & $\boldsymbol{E}$ & $\boldsymbol{G I}$ & $\boldsymbol{G} \boldsymbol{O}$ & $\boldsymbol{O}$ F & $\boldsymbol{O}$ & $\Delta \boldsymbol{S}$ & $\boldsymbol{r}$ & $\begin{array}{c}\boldsymbol{r} \\
\text { (percent) }\end{array}$ \\
\hline Clara & 1981 & 774 & 684 & 74 & 161 & 3 & 72 & -42 & -24 & -3 \\
& 1982 & 840 & 643 & 48 & 197 & 90 & 253 & 47 & -162 & -16 \\
& 1983 & 962 & 677 & 144 & 113 & 137 & 214 & 35 & 204 & 18 \\
& 1981 & 697 & 624 & 183 & 406 & - & - & -129 & -21 & -2 \\
& 1982 & 976 & 611 & 140 & 425 & - & - & 89 & -9 & -1 \\
& 1983 & 988 & 585 & 195 & 341 & - & - & 186 & 71 & 7 \\
\hline
\end{tabular}
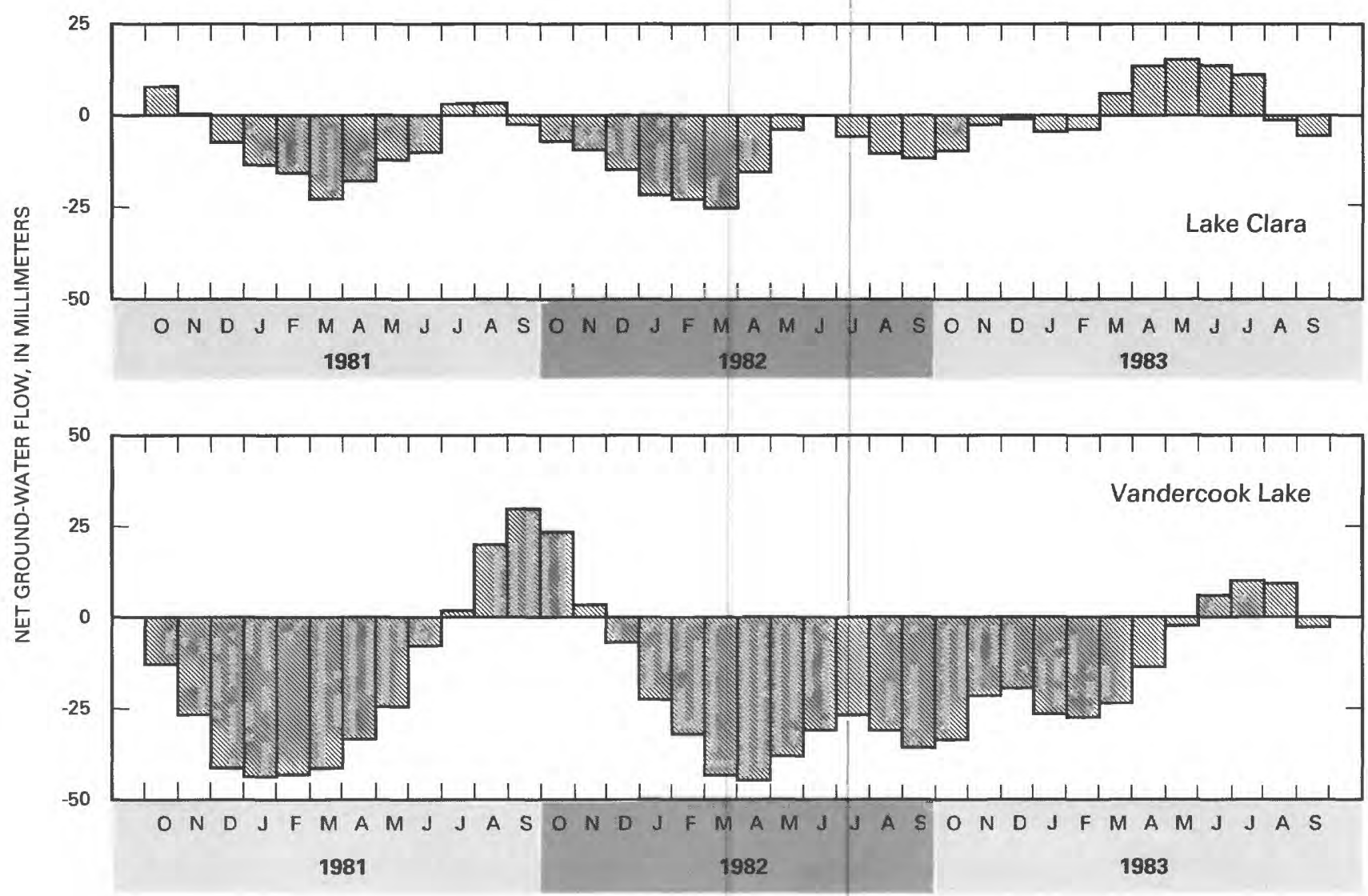

\section{WATER YEAR}

Figure 15. Monthly net ground-water flow to and from Lakes Clara and Vandercook. (Positive values represent ground-water inflow; negative values represent ground-water outflow.) 
Table 8.-Percentage composition of inflow and outflow

[ -, nonexistent; $\boldsymbol{P}$, precipitation; $\boldsymbol{E}$, evaporation; $\boldsymbol{G I}$, ground-water inflow; $G O$, ground-water outflow; $O F$, overland flow; $O$, surface outflow.]

\begin{tabular}{|c|c|c|c|c|c|c|c|}
\hline \multirow[b]{2}{*}{ Lake } & \multirow[b]{2}{*}{$\begin{array}{l}\text { Water } \\
\text { year }\end{array}$} & \multicolumn{3}{|c|}{ Inflow } & \multicolumn{3}{|c|}{ Outflow } \\
\hline & & $P$ & GI & $O F$ & $\boldsymbol{E}$ & GO & $\boldsymbol{O}$ \\
\hline \multirow[t]{3}{*}{ Clara } & 1981 & 91 & 9 & $<1$ & 75 & 17 & 8 \\
\hline & 1982 & 86 & 5 & 9 & 59 & 18 & 23 \\
\hline & 1983 & 77 & 12 & 11 & 68 & 11 & 21 \\
\hline \multirow[t]{3}{*}{ Vandercook } & 1981 & 79 & 21 & - & 61 & 39 & - \\
\hline & 1982 & 87 & 13 & - & 59 & 41 & - \\
\hline & 1983 & 84 & 16 & - & 63 & 37 & - \\
\hline
\end{tabular}
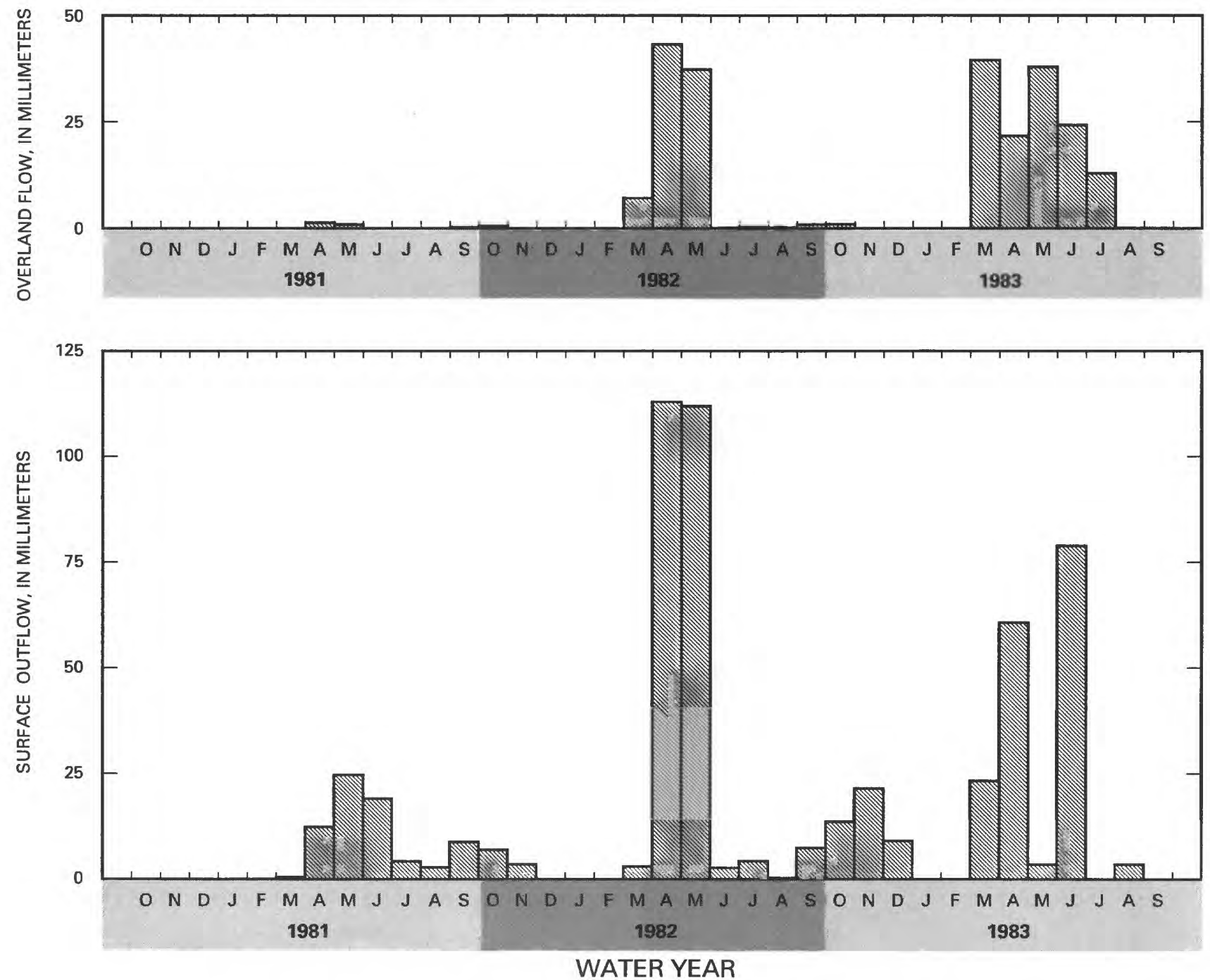

Figure 16. Monthly overland flow to and surface outflow from Lake Clara. 
physical processes will be less than those calculated from equation 10.

Hydraulic and chemical residence times were similar at Lakes Clara and Vandercook during the 3-year study (table 9). Chemical residence times for the lakes also were similar, except during the 1981 water year when surface outflow from Lake Clara was small (table 7). Chemical residence times were 2.5 to 4.2 times greater than hydraulic residence times.

\section{SUMMARY}

Water-budget investigations were conducted at Lakes Clara and Vandercook in north-central Wisconsin during the 1981-83 water years. The studies were done to provide knowledge of the interactions of seepage lakes with their hydrologic environments in areas that potentially could be impacted by acid deposition.

Total annual precipitation at Lakes Clara and Vandercook was 3 and 16 percent below normal, respectively, during the 1981 water year; precipitation was 6 to 21 percent above normal during the 1982 and 1983 water years. Monthly distributions were similar, with most precipitation (63 to 76 percent) falling as rain from May through October. Peak watershed snowpacks were 130 to $132 \mathrm{~mm}$ water equivalent during March 1982 and 118 to $126 \mathrm{~mm}$ during February 1983. Water equivalent of snow on lake ice was only 16 to 70 percent of that in the watershed, probably because of sublimation and wind removal of snow from lake ice, and incorporation of snow into ice cover. Snowmelt was complete by the end of April 1982 and by the end of March 1983.

Lake stage and water-table altitudes followed similar trends at each study area; spring increases were caused by snowmelt and rainfall, and summer declines were caused by evaporation. The annual mean lake stage and water table changed little at Lake Clara during the 3 water years of study and at Vandercook Lake during the 1981 and
1982 water years. During the 1983 water year at Vandercook Lake, stage increased about $0.2 \mathrm{~m}$, and the upgradient water-table increased about $0.3 \mathrm{~m}$. Watertable-contour maps show that Lake Clara was a groundwater recharge lake in a local flow system, whereas Vandercook Lake was a ground-water flow-through lake in a regional flow system.

Absolute values of hydrologic-budget residuals were smaller at Vandercook Lake than at Lake Clara. The hydrologic budgets indicate that inputs to Lakes Clara and Vandercook were dominated by precipitation ( 77 to 91 percent of total inflow). Both lakes received significant amounts of ground-water inflow (5 to 12 percent at Lake Clara and 13 to 21 percent at Vandercook Lake); however, only Lake Clara received inflow from overland flow (as much as 11 percent). Outflow from the lakes was predominantly by evaporation ( 59 to 75 percent). The remaining outflow from Vandercook Lake (37 to 41 percent) was to the ground-water system, whereas Lake Clara lost 11 to 18 percent of its water by ground-water outflow and 8 to 23 percent by surface outflow. Budget residuals for Vandercook Lake were smaller $(-1$ to +7 percent) than for Lake Clara $(-16$ to +18 percent). This may have resulted from problems in determining budget contributions from overland flow and surface outflow at Lake Clara. Hydraulic residence times were 4 to 5 years at both lakes. Chemical residence times for conservative constituents were 10 to 13 years at Vandercook Lake and 11 to 21 years at Lake Clara.

\section{REFERENCES}

Attig, J. W., 1985, Pleistocene geology of Vilas County, Wisconsin: Wisconsin Geological and Natural History Survey Information Circular 50, Madison, 32 p., 1 pl. Bouwer, H., and Rice, R.C., 1976, A slug test for determining hydraulic conductivity of unconfined aquifers with completely or partially penetrating wells: Water Resources Research, v. 12, p. 423-428.

Table 9.-Hydraulic and chemical residence times

\begin{tabular}{lcc|c}
\hline Lake & Water year & $\begin{array}{c}\text { Hydraulic residence } \\
\text { time } \\
\text { (years) }\end{array}$ & $\begin{array}{c}\text { Chemical residence } \\
\text { time } \\
\text { (years) }\end{array}$ \\
\hline Clara & 1981 & 5 & 21 \\
& 1982 & 4 & 11 \\
& 1983 & 5 & 15 \\
Vandercook & 1981 & 4 & 11 \\
& 1982 & 4 & 10 \\
& 1983 & 5 & 13 \\
\hline
\end{tabular}


Buchanan, T.J., and Somers, W.P., 1968, Stage measurement at gaging stations: U.S. Geological Survey Techniques of Water-Resources Investigations, book 3 , chap. A7, $28 \mathrm{p}$.

Cogbill, C.V., 1976, The history and character of acid precipitation in eastern North America: Water, Air, and Soil Pollution, v. 6, p. 407-413.

Cogbill, C. V., and Likens, G.E., 1974, Acid precipitation in the northeastern United States: Water Resources Research, v. 10, p. 1,133-1,137.

Dunne, T., and Leopold, L.B., 1978, Water in environmental planning: W. H. Freeman and Company, San Francisco, 818 p.

Farnsworth, R. K., Thompson, E.S., and Peck, E. L., 1982, Evaporation atlas for the contiguous 48 United States: National Oceanic and Atmospheric Administration Technical Report NWS 33, 26 p., 4 pls.

Field, S. J., and Duerk, M. D., 1988, Hydrology and water quality of Delavan Lake in southeastern Wisconsin: U.S. Geological Survey Water-Resources Investigations Report 87-4168, 61 p.

Freeze, R.A., and Cherry, J.A., 1979, Groundwater: Prentice-Hall, Inc., Englewood Cliffs, N.J., 604 p.

Garstka, W. W., 1964, Snow and snow survey, in Chow, V.T., ed., Handbook of applied hydrology: McGrawHill, N.Y., p. 10-1 to 10-57.

Goodison, B. E., 1981, Compatibility of Canadian snowfall and snow cover data: Water Resources Research, v. 17, p. 893-900.

Gow, A. J., and Govoni, J. W., 1983, Ice growth on Post Pond, 1973-1982: CRREL Report 83-4, U.S. Army Cold Regions Research and Engineering Laboratory, Hanover, N.H., 25 p.

Gow, A. J., and Langston, D., 1977, Growth history of lake ice in relation to its stratigraphic, crystalline and mechanical structure: CRREL Report 77-1, U.S. Army Cold Regions Research and Engineering Laboratory, Hanover, N.H., 24 p.

Hackbarth, D.A., 1968, Hydrogeology of the Little St. Germain Lake basin, Vilas County, Wisconsin: M.S. thesis, University of Wisconsin, $76 \mathrm{p}$.

Hadley, D. W., 1976, Glacial geology, in Mineral and water resources of Wisconsin: Report for use of U.S. Senate Committee on Interior and Insular Affairs, 94th Congress, 2nd Session, U.S. Government Printing Office, Washington, D.C., p. 38-55.

Haeni, F.P., 1983, Application of seismic refraction techniques to hydrologic studies: U.S. Geological Survey Techniques of Water-Resources Investigations, book 2, chap. D2, 118 p.

Hennings, R.G., 1978, The hydrogeology of a sand plain seepage lake, Portage County, Wisconsin: M.S. thesis, University of Wisconsin, $70 \mathrm{p}$.

Hole, F.D., 1976, Soils of Wisconsin: University of Wisconsin Press, Madison, 223 p., 1 pl.
House, L.B., 1984, Effects of urbanization on three ponds in Middleton, Wisconsin: U.S. Geological Survey Water-Resources Investigations Report 84-4051, 17 p., 1 pl.

Kontis, A.L., and Mandle, R.J., 1980, Data-base system for northern Midwest Regional Aquifer-System Analysis: U.S. Geological Survey Water-Resources Investigations 80-104, $23 \mathrm{p}$.

Linsley, R.K.,Jr., Kohler, M.A., and Paulhus, J.L.H., 1975, Hydrology for engineers (2nd ed.): McGraw-Hill, New York, 482 p.

Martin, L., 1965, The physical geography of Wisconsin (3rd ed.): University of Wisconsin Press, Madison, $608 \mathrm{p}$.

McLeod, R. S., 1980, The effects of using ground water to maintain water levels of Cedar Lake, Wisconsin: U.S. Geological Survey Water-Resources Investigations Report 80-23, 35 p.

Mooney, H.M., 1980, Handbook of engineering geophysics, Volume 1, Seismic: Bison Instruments, Inc., Minneapolis, Minn., 220 p.

Mudrey, M.G., Jr., Brown, B.A., and Greenberg, J.K., 1982, Bedrock geologic map of Wisconsin: Geological and Natural History Survey, University of Wisconsin-Extension, scale 1:1,000,000.

National Oceanic and Atmospheric Administration, 1972, National Weather Service observing handbook no. 2-substation observations (revised): U.S. Department of Commerce, $77 \mathrm{p}$.

Novitzki, R. P., and Holmstrom, B. K., 1979. Monthly and annual water budgets of Lake Wingra, Madison, Wisconsin, 1972-77: U.S. Geological Survey WaterResources Investigations 79-100, 31 p.

Oakes, E. L., Hendrickson, G.E., and Zuehls, E.E., 1975, Hydrology of the Lake Wingra basin, Dane County, Wisconsin: U.S. Geological Survey Water-Resources Investigations $17-75,31 \mathrm{p}$.

Okwueze, E.E., 1983, Geophysical investigations of the bedrock and the ground water-lake flow system in the Trout Lake region of Vilas County, northern Wisconsin: Ph.D. thesis, University of Wisconsin, $130 \mathrm{p}$.

Possin, B.D., 1973, The hydrogeology of Mirror and Shadow Lakes in Waupaca, Wisconsin: M.S. thesis, University of Wisconsin, $83 \mathrm{p}$.

Rantz, S. E., and others, 1982a, Measurement and computation of streamflow: Volume 1, Measurement of stage and discharge: U.S. Geological Survey WaterSupply Paper 2175, p. 1-284.

$1982 \mathrm{~b}$, Measurement and computation of streamflow: Volume 2, Computation of discharge: U.S. Geological Survey Water-Supply Paper 2175, p. 285-631.

Rickmers, A.D., and Todd, H.N., 1967, Statistics-An introduction: McGraw-Hill, N.Y., 585 p. 
Scott, J.H., Tibbetts, B.L., and Burdick, R.G., 1972 , Computer analysis of seismic refraction data: U.S. Bureau of Mines Report of Investigations 7595, 95 p. Tolman, A. L., 1975, The hydrogeology of the White Clay Lake area, Shawano County, Wisconsin: M.S. thesis, University of Wisconsin, $127 \mathrm{p}$.

Wentz, D.A., and Rose, W.J., 1989, Interrelationships among hydrologic-budget components of a northern Wisconsin seepage lake and implications for aciddeposition modeling: Archives of Environmental Contamination and Toxicology, v. 18, p. 147-155.

Wentz, D.A., Rose, W.J., and Krohelski, J.T., 1989, Hydrologic component, in Knauer, D., and S.A. Brouwer, eds., The Wisconsin Regional Integrated Lake-Watershed Acidification Study (RILWAS): 1981-1983: Electric Power Research Institute Report EA-6214, Palo Alto, Calif., p. 5-1 to 5-77.
Winter, T.C., 1978, Ground-water component of lake water and nutrient budgets: Verhandlung Internationale Vereingung Limnologie, v. 20, p. 438-444. 1981, Uncertainties in estimating the water balance of lakes: Water Resources Bulletin, v. 17, p. 82-115.

Wisconsin Agricultural Reporting Service, 1978, Snow and frost in Wisconsin, 1961-1977: Wisconsin Agricultural Reporting Service, Madison, 38 p.

Wisconsin Department of Natural Resources, 1980, A review of acid deposition in Wisconsin; Recommendations for studying and solving the problem: Wisconsin Department of Natural Resources, Acid Deposition Task Force, Madison, $46 \mathrm{p}$. 